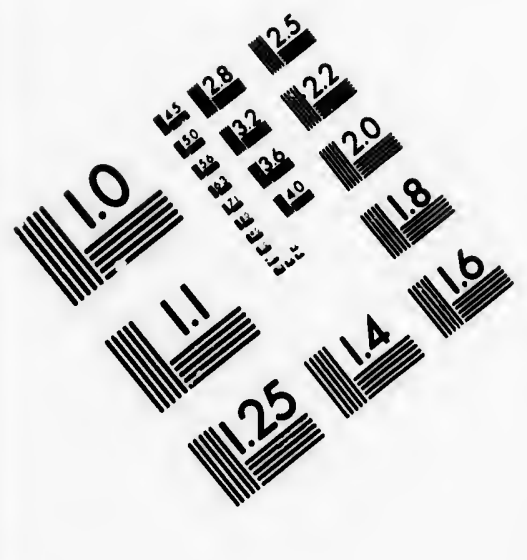

IMAGE EVALUATION
TEST TARGET (MT-3)
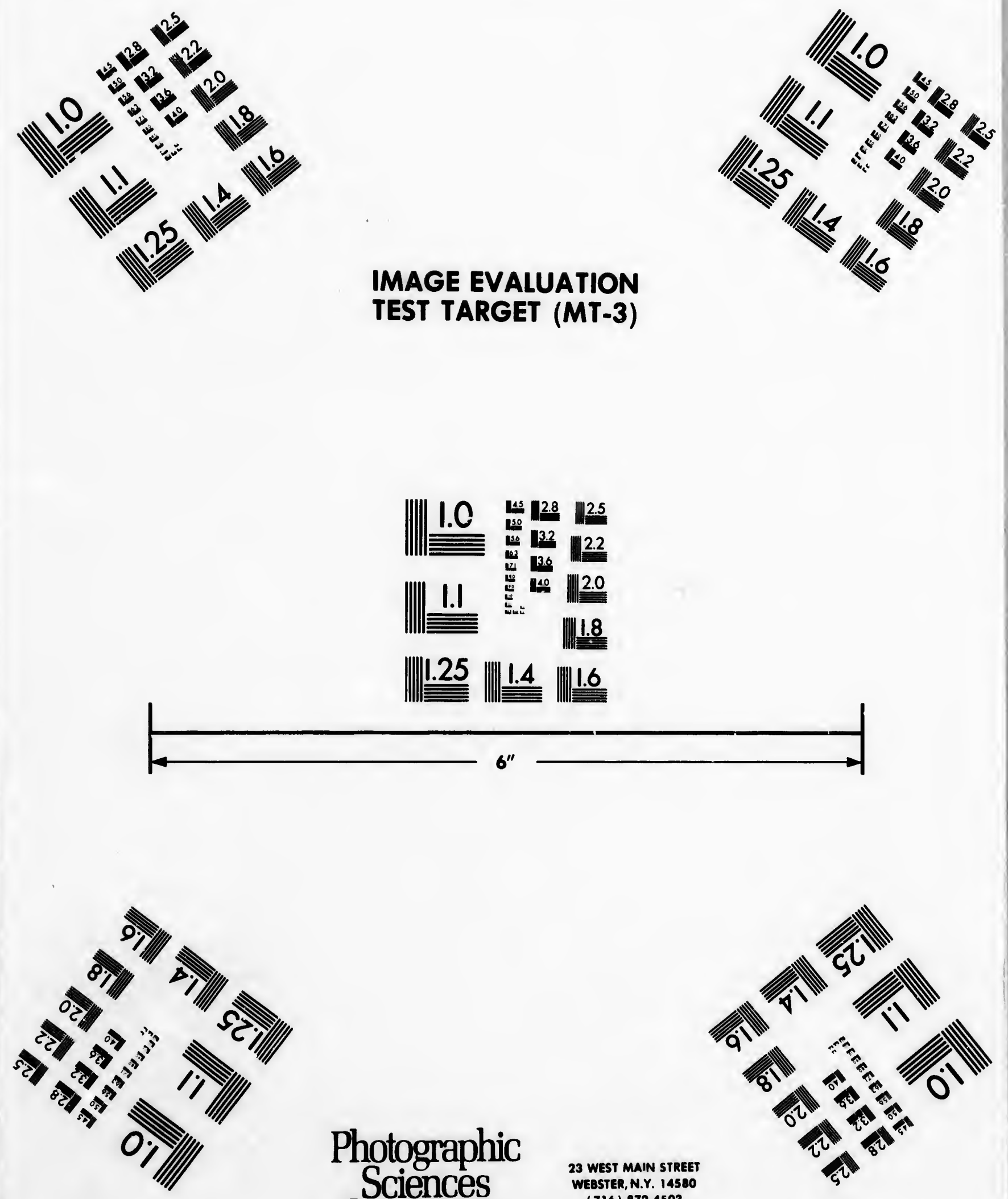

Photographic Sciences Corporation

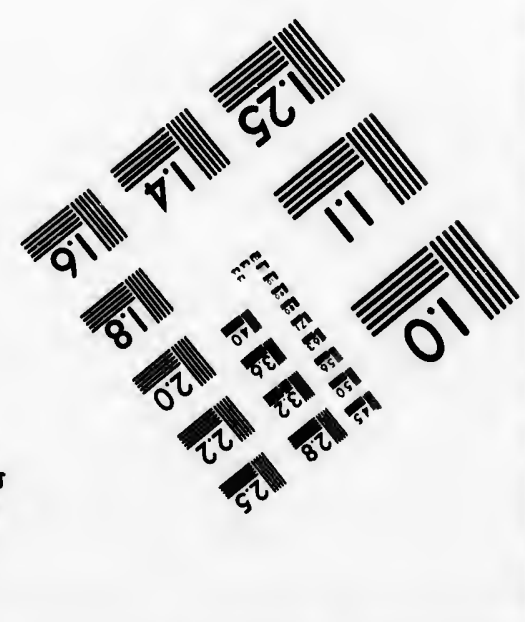



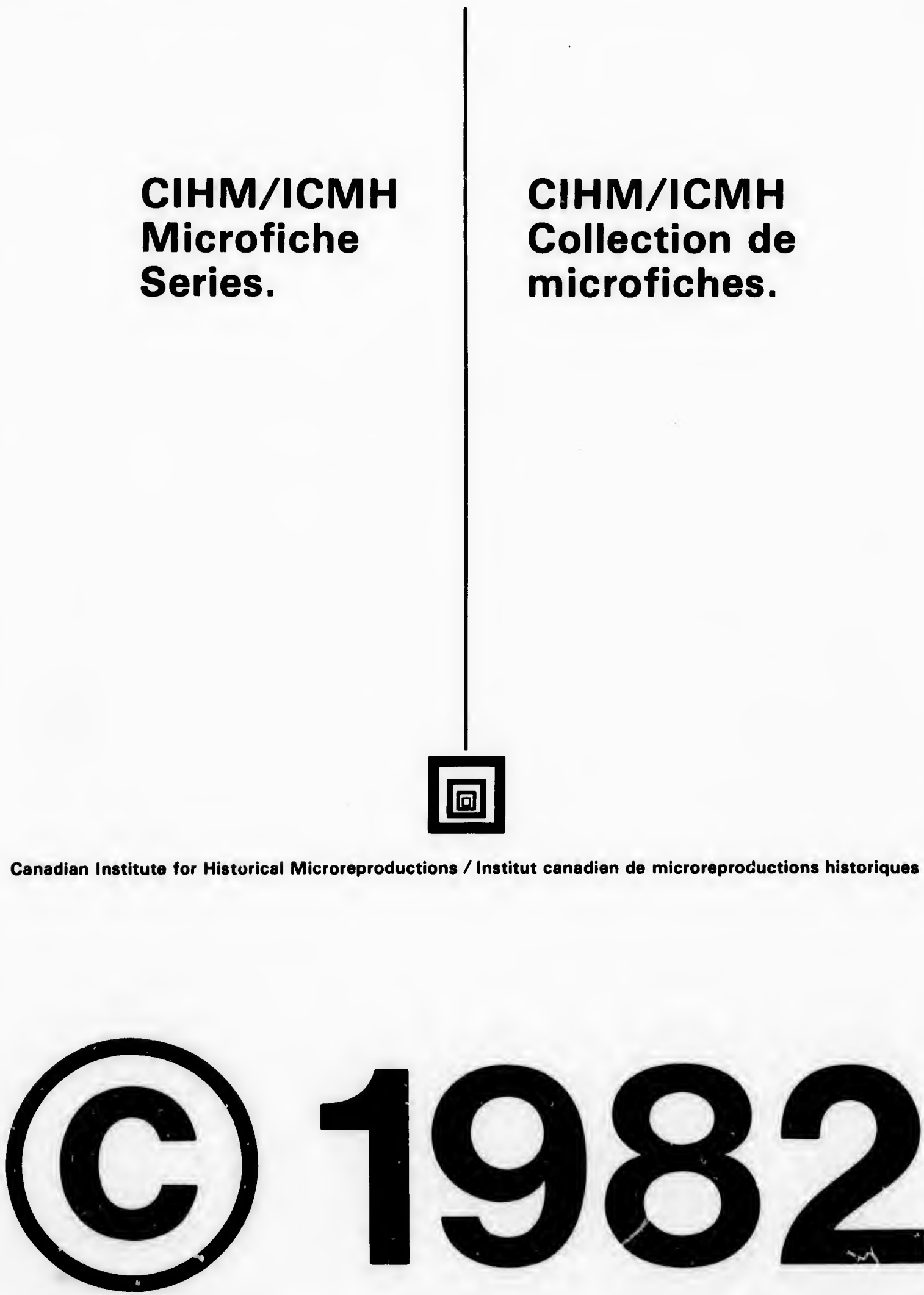
The institute has attempted to obtain the best original copy available for filming. Foatures of this copy which may be bibliographically unique.

which may alter any of the images in the reproduction, or which may significantly chenge the usual method of filming, are checked below.

Coloured covers'

Couverture de couleur

Covers damaged/

Couverture endommageo

$凶 \cos$

Covors restored and/or laminated/

Couverture restaurbe et/ou pelliculé

Cover title missing/

Le titre de couverture manque

Coloured maps/

Cartes goographiques on couleur

Coloured ink (i.e. other than blue or bleck)/

Encre de couleur (i.e. autre que bleue ou noire)

Coloured plates end/or illustretions/

Planches ot/ou illustrations on couleur

Bound with other material/

Relib avec d'autres documents

Tight binding may cause shadows or distortion along interior margin/

La reliure serré faut causer de l'ombre ou de le distortion le long de la marge intórieure

Blank leaves added during restoration may

appear within the text. Whenever possible, these heve been omitted from filming/

II se peut que certaines pages blanches ajoutces lors d'une restauration apparaissent dans le texte. - gis, lo rsque cela otait possible, ces pages n'ont pas etc filmbes.

Additional comments:/

Commentaires supplémentaires:
L'Institut a microfilmo lo meilleur exemplaire qu'il lul a bt' possible de se procurer. Les détails de cet exemplaire qui sont peut-stre uniques du point de vue bibliographique, qui peuvent modifier une image reproduite, ou qui peuvent exiger une modification dans la móthode normale de filmage sont indiquós ci-dessous.

Coloured pages/

Pages de couleur

Pages damaged/

Pages endommagés

Pages reatored and/or laminated/

Pages restaurées et/ou peliticulées

Pages discoloured, stained or foxed/

Pages décolorées, tachetbes ou piquées

Pages deteched/

Pages détachées

Showthrough/

Transparence

Quality of print varies/

Qualité iń́gale de l'impression

Includes supplementary material/

Comprend du matóriel supplómentaire

Only edition evailable/

Soule odition disponible

Pages wholly or partially obscured by errote slips, tissues, etc., have been refiimed to onsure the best possible image/ Les pages totalement ou partiellement obscurcies par un feuillot d'errate, une pelure. otc.. ont b́tb filmbes nouveau de façon a obtenir la meilleure image possible.

This item is filmed at the reduction ratio checked below/ Co document est filmb au taux de róduction indiqué ci-dessous.

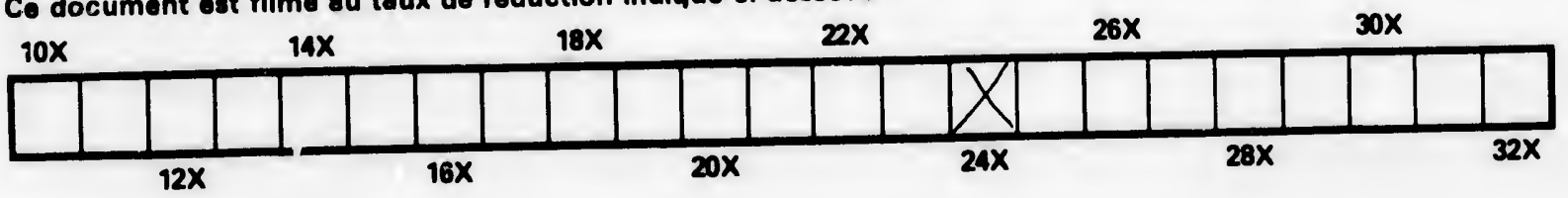


The copy filmed here hes been reproduced thanks to the generosity of:

Library of Congress

Photoduplication Service

The images appearing here are the best quality possible considering the condition and legibility of the original copy and in keaping with the filming contract specifications.

Original copies in printed paper covers are filmed beginning with the front cover and ending on the last page with a printed or illustrated impres. sion, or the back cover when appropriate. All other original copies are filmed beginning on the first page with a printed or illustrated impres. sion, and ending on the last page with a printed or illustrated impression.

The last recorded frame on each microfiche shall contain the symbol $\rightarrow$ Imeaning "CON. TINUED"), or the symbol $\nabla$ (meaning "END"). whichever appiies.

Maps, plates, charts, etc., may be fiimed at different reduction ratios. Those too large to be entirely included in one exposure are filmed beginning in the upper left hand corner, left to right and top to bottom, as many frames as required. The following diagrams illustrate the method:
L'exemplaire fllmo fut reproduit grâce à la génórosité do:

\author{
Library of Congrass \\ Photoduplication Service
}

Les images suivantes ont été reproduites avec le plus grand soin, compte tenu de la condition et de la notteté do l'exemplaire filmb, et en conformitó avac les conditions du contrat de filmage.

Les exemplaires origineux dont la couverture en papier est imprimbe sont filmés en commençant par le premier plat et en terminant soit par la derniére page qui comporte une empreinte d'impression ou d'illustration, soit par le second plat, selon le cas. Tous les autres exemplaires originaux sont filmes en commençent par la premidre page qui comporte une empreinte d'impression ou d'illustration et en terminant par la dernibre page qui comporte une teile empreinte.

Un des symboles suivents apparaître sur le derniére image de chaque microfiche, si ion le cas: 10 symbole $\rightarrow$ signifie "A SUIVRE", le symbole $\nabla$ signifie "FIN".

Les cartes, planches, tableaux, etc., peuvent être filmbs des taux de róduction differents. Lorsque le document est trop grand pour être reproduit on un seul clichb, il est filmb a partir de l'angle supórieur gauche, de gauche a droite. ot do haut on bas, on prenant le nombre d'images n6́cessaire. Les diagrammes suivants illustrent la methode.

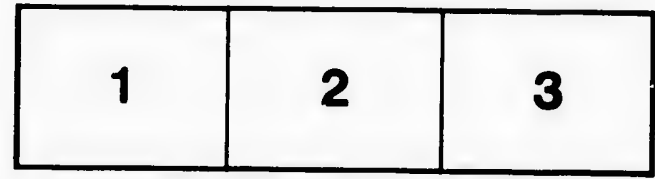
elure,
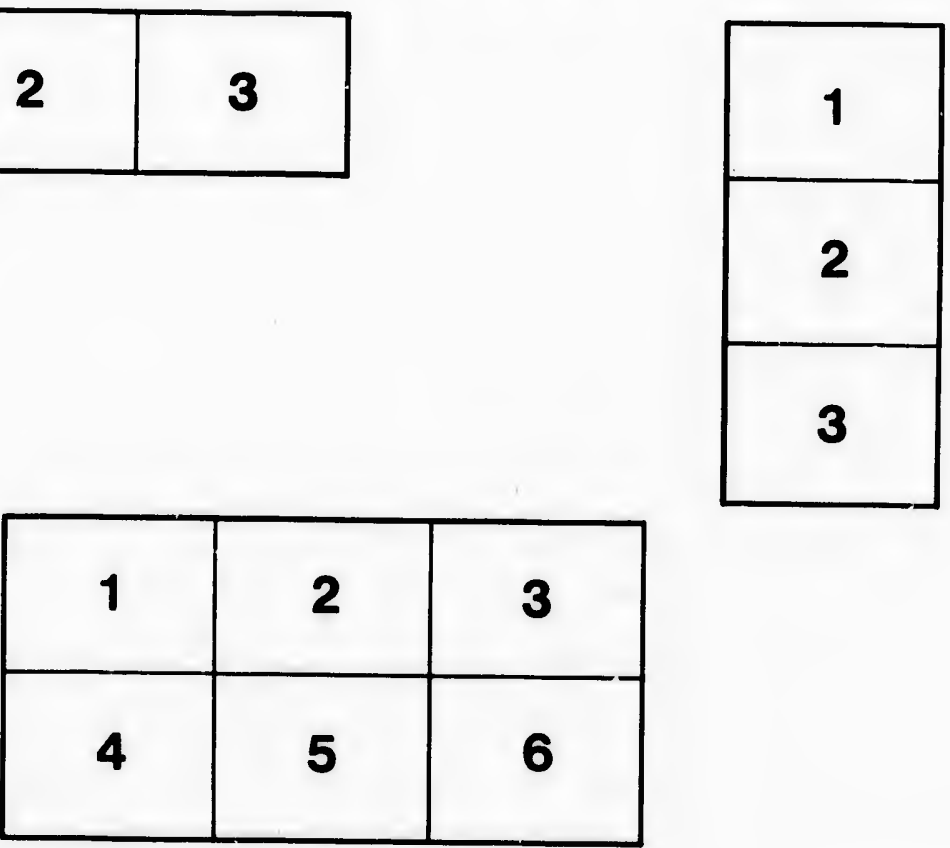


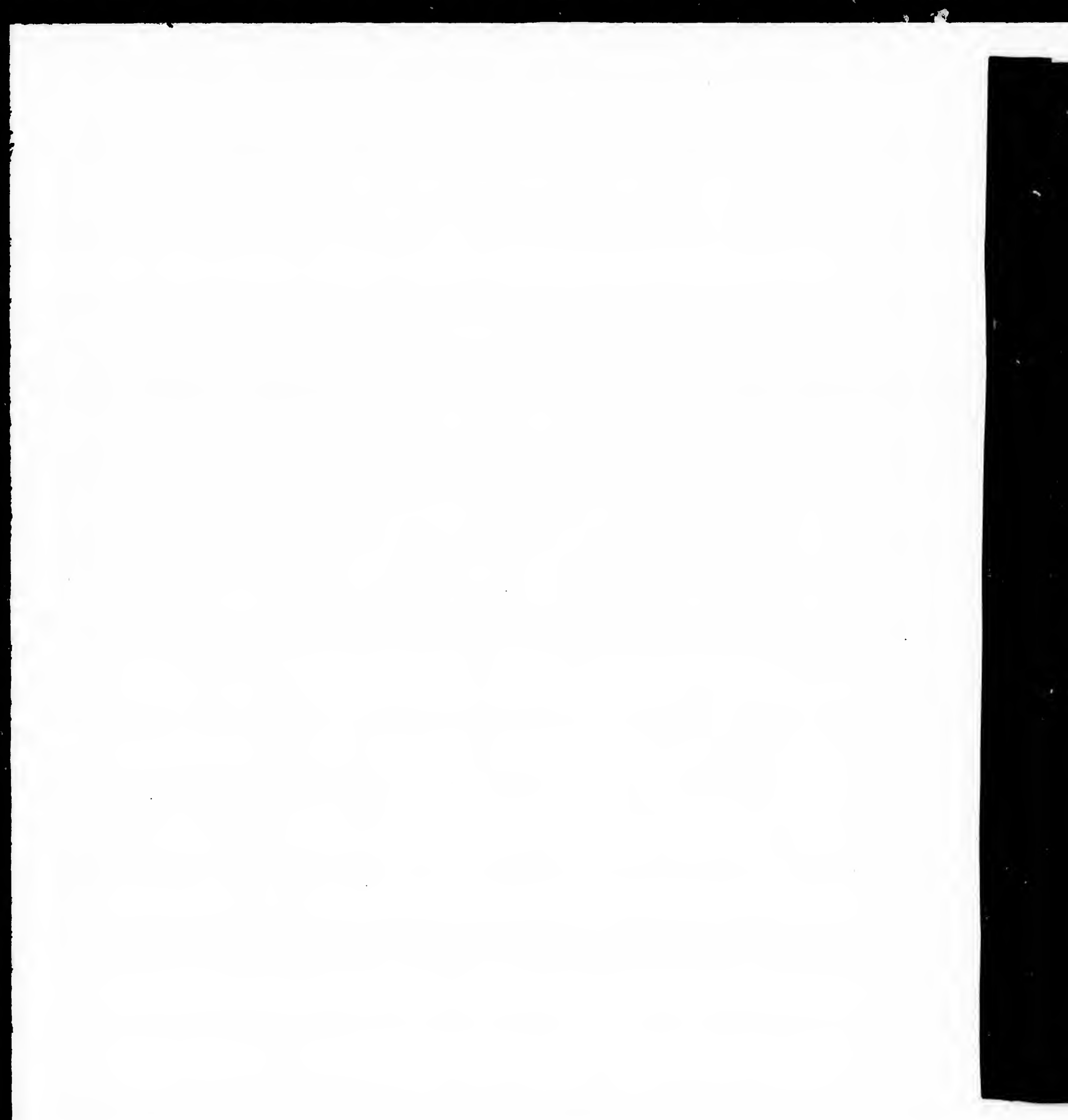




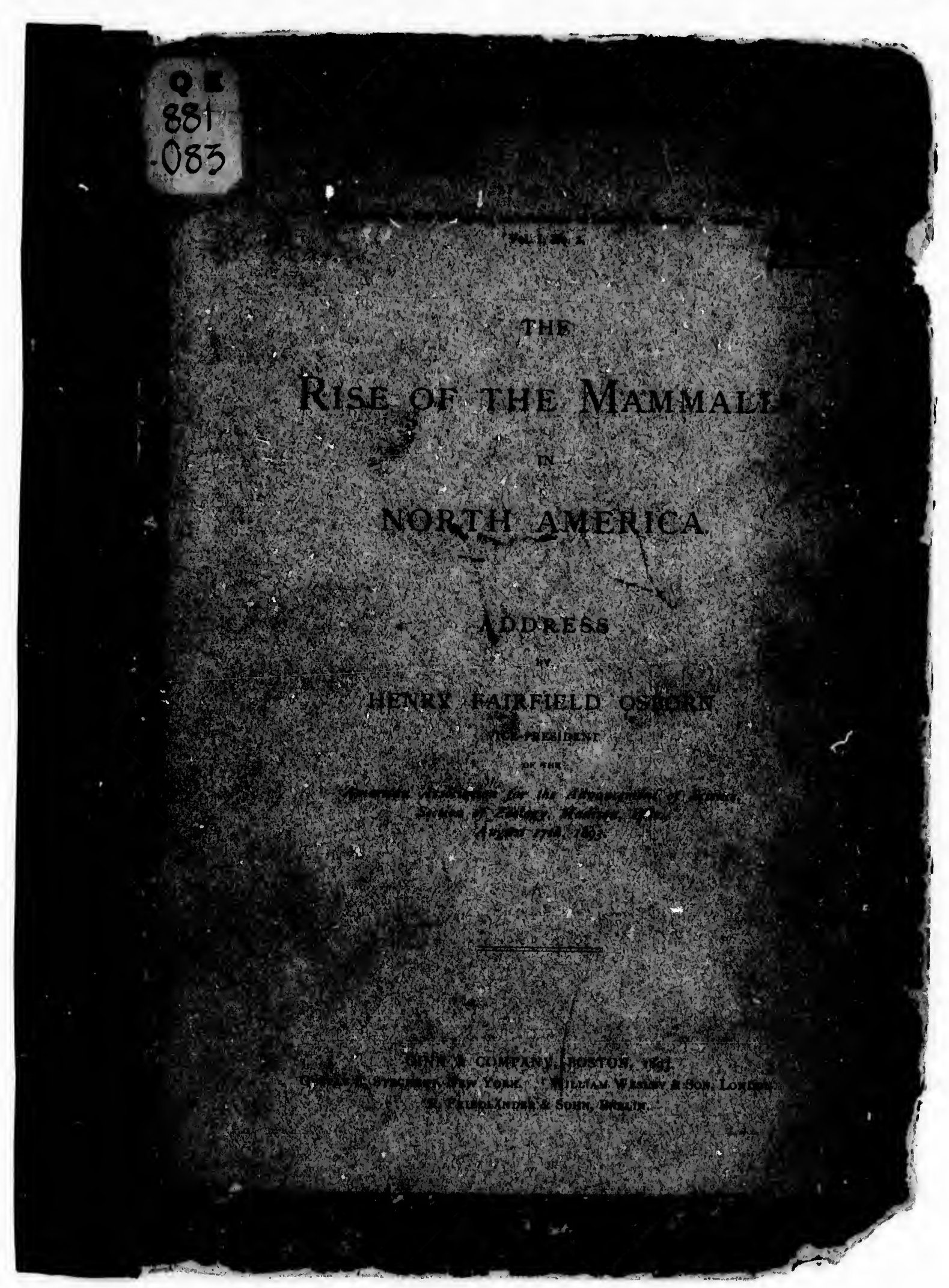




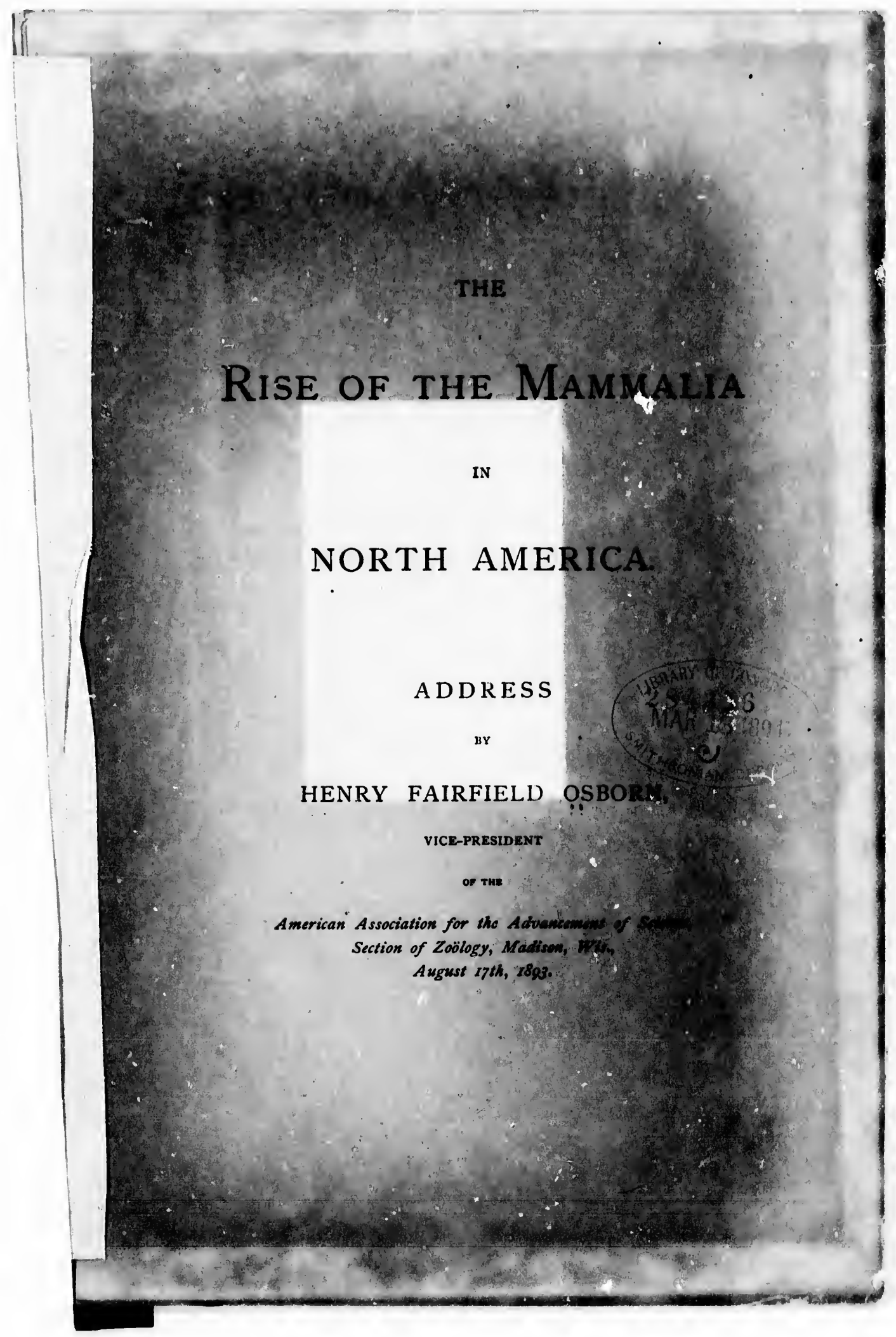


QE
$08^{1}$
$08^{3}$

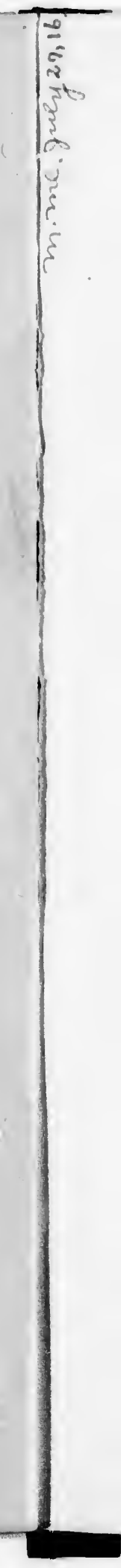




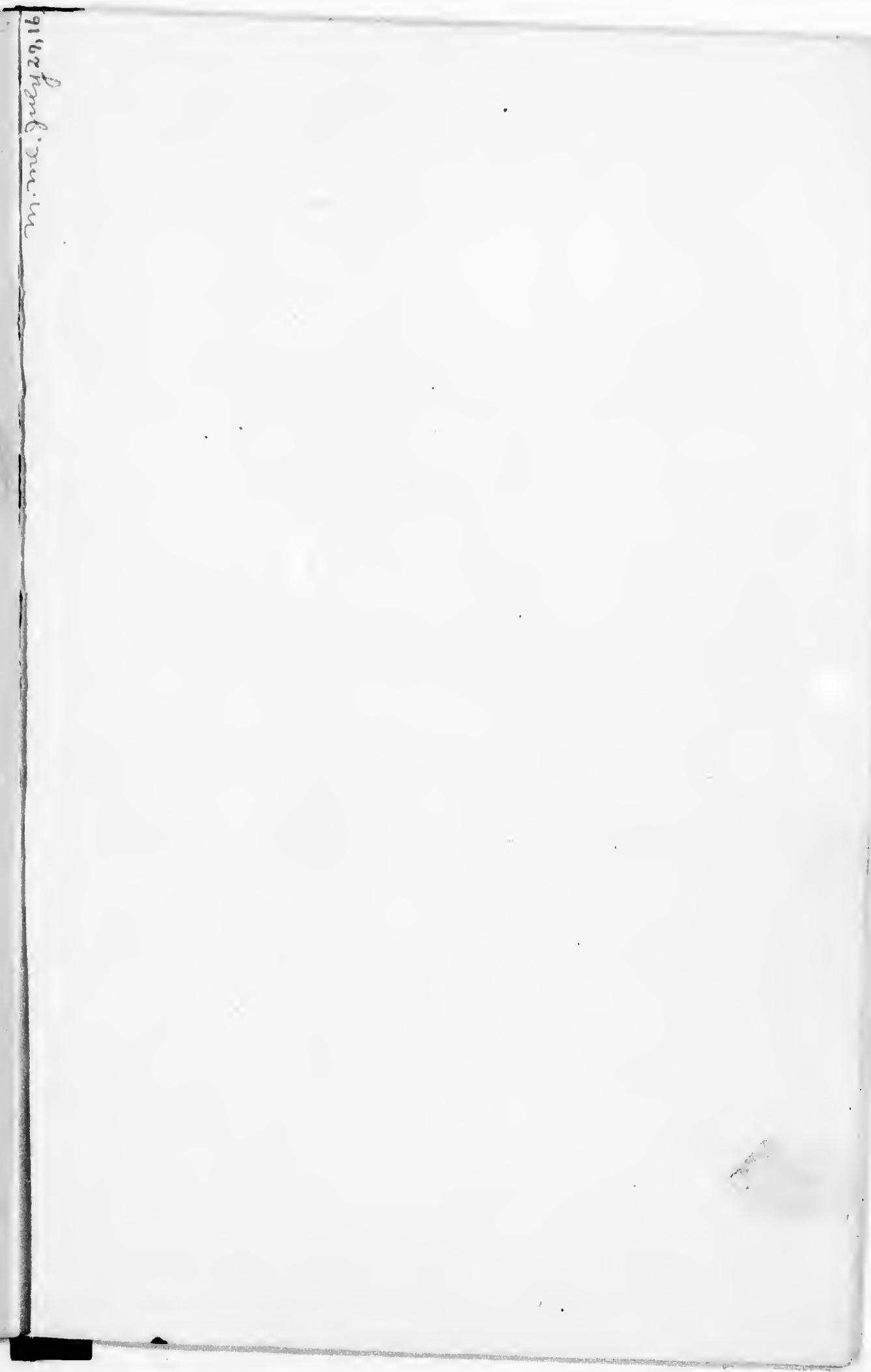




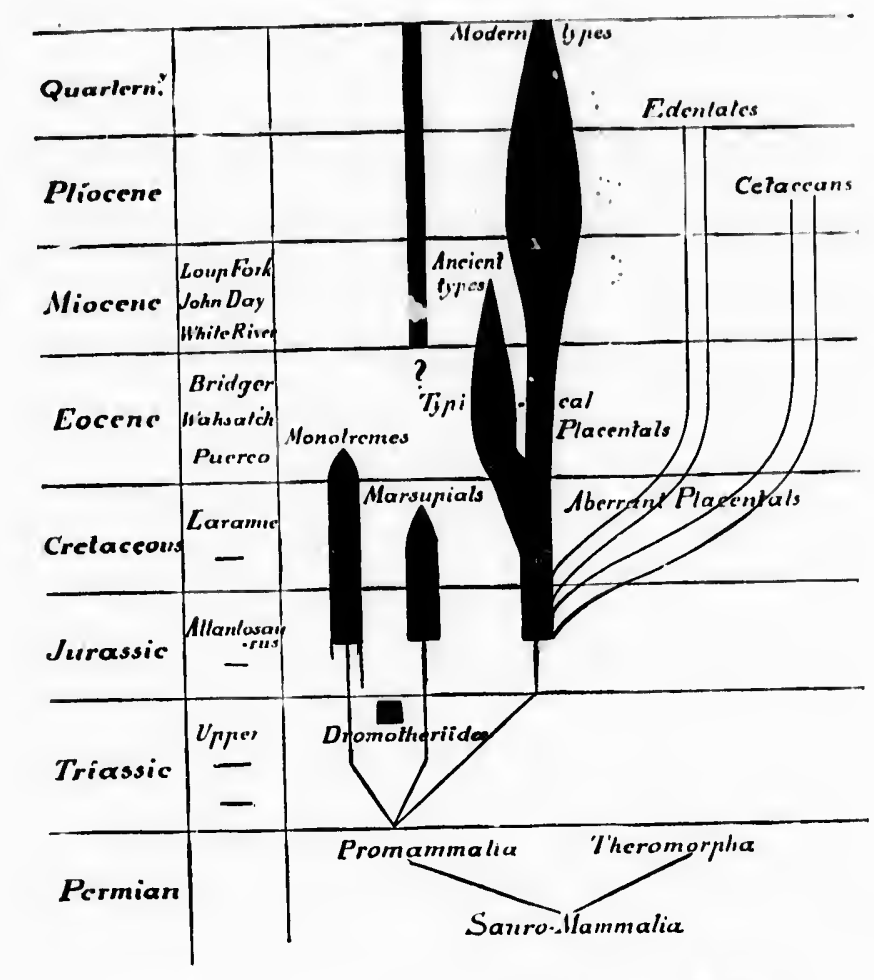

Hytuthetical Plyllogeny of the North Ameriatm Manmmalit.

The Monotremes disappear in the basal locene. The Marsupia!s dicappear in the upper Cretaceous and reappear in the lower M:ocene (1)idilphys). The aber the upper Cre typical l'acentals divide into the "Ancient types" dying out in the Miocene, and the "Modern types" still existing. The aberrant Placentals are given off in mid-Mesozoic times. 


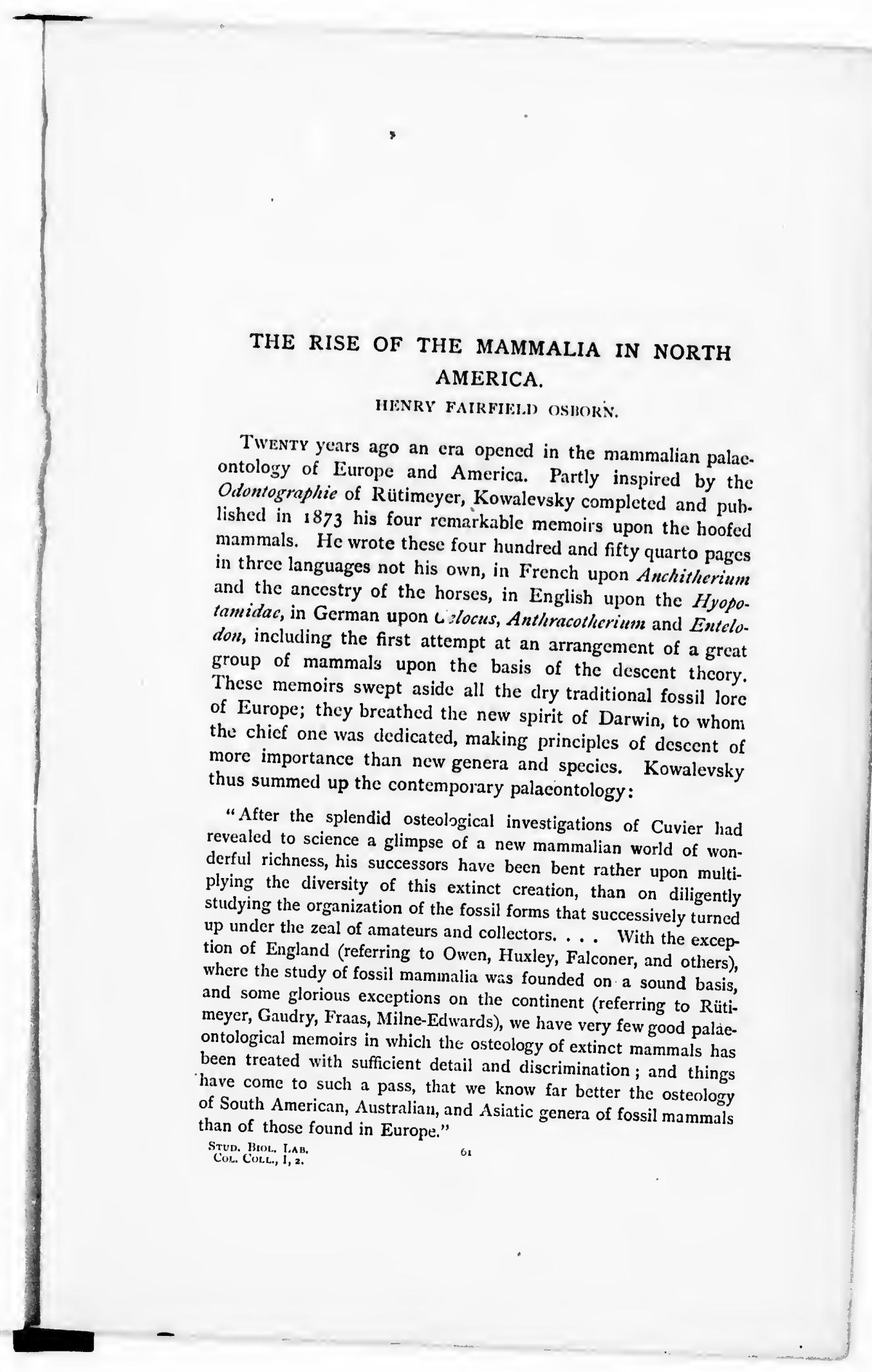


At the same time, between 1871 and 1873 , the pioneers of American palacontology, Leidy, Marsh, and Cope began the exploration of our ancient lake basins rich in life. The first ten years of their work not only revolutionized our ideas of mammalian descent, but brought together the data for the generalizations of the second decade; for Marsh's demonstration of the laws of brain evolution in relation to survival; for Cope's proof of ungulate derivation from types with the simple foot resting upon the sole, and with the conic or bunodont ancestral molar tooth; and finally for Cope's demonstration of the tritubercular molar as the central type in all the mam. malia. These four generalizations furnished a new working basis for morphology and phylogeny.

In these twenty years, thanks to energetic field work, we have accumulated vast materials for the history of the rise of the mammalia, enough for ten students where there is one, and the question arises: how shall we take best advantage of it, what methods shall we adopt? In this address, besides bringing before you the more recent achievements of exploration and research, I will try to illustrate the advances already made in lines of thought, observation and system in palacontology and indicate other advances which seem to me still desirable. In the problem of how to think and work most effectively, and with most permanent results, all the sciences meet on common ground.

\section{Advances in Mfthod.}

It is to the renown of the veteran Ruitimeyer and of Kowalevsky, so soon unfortunately deceased, that, while their main inductions suffer by American discoveries, their methods of thought have not been displaced. It matters little that their theory, that ungulate molars sprang from lophodont or crested forms, has been disproved; that Kowalevsky's tables of descent are full of errors; that his main generalization as to the persistence of adaptive and extinction of inadaptive foot types does not hold good; that the horses and Anchitherium spring not from Palaeotherium as he supposed, but from Pachynoloplius 
and IJyracotherium, types which he carefully studied and yet omitted from the horse line! It is the right system of thought which is most essential to progress; better in the end wrong results such as the above, reached by the right method, than right results reached hap-hazard by a vicious method. If a student asks me how to study palacontology, I can do no better than direct him to the Virsuch einer natilliclicn Classi. fication der fossilen Hufthicre, out of clate in its facts, thoroughly modern in its approach to aricient nature. This work is a model union of the cletailed study of form and function with theory and the working hypothesis. It regards the fossil not as a petrificel skeleton, but as moving and feeding; cvery joint and facet has a meaning, each cusp a certain significance. Rising to the philosophy of the matter, it brings the mechanical perfection and adaptiveness of different types into relation with environment, the change of herbage, the introduction of grasses. In this competition it speculates upon the causes of the rise, spread and extinction of each animal group. In other words the fossil quadrupeds are treated biologically - so far as possible in the obscurity of the past. From such models and from our own experience we learn to fecl free to abandon traditions in the use of the tools of science, such as mere methods of descrip. tion and classification, and to regard priority in nomenclature
only.

New discoveries continually produce new conditions; there is nothing more obstructive than the reverence for old ideas and systems which have outlived their usefulness. In observation, an old principle was de millimis non curat lcx; now, we cannot be too exact. Every cusp and facet has its value, not as a sign-post for a new species, but as suggestive of some function or relationship. Bird's-eye methods of comparison, which, for example, find no difference between a rhinoceros and a lophiodon molar, a : of no service now that we are called upon to distinguish between so $m_{t}$ !ny lines of ancient mammals crowding in among the ancestors of existing mammals. Again, palaeontology is not a science apart; it has always gone hand in hand with recent osteology; it must now keep abreast with the embryology of the teeth and skele- 
ton; with the animal mechanics of Marcy, Allen, and Muy. bridge; with palacobotany, gcology, and historical-physical geography. In these points we cannot be too broad. All structures should be considered as to their homologies, their mechanics, which throw such a brillian light upon their cvolution; their relations to the food and soil, and to other parts. This brings us to the animal as a whole - its tendencies, its place in the system of descent, its relations to its contemporarics, the causes of its progression or retrogression; finally, into pure speculation. IJcre I am reminded of a critical saying by the late Professor v. Gudden, the distinguished nel1rologist : "Ein Steinchen der Wahrheit hat mehr Werth als ein grosser Schwindelbau" ; it was in allusion to the temporary character of the great nerve-tract systems of Meynert and Flechsig. The great 'Schwindelbau,' literally the 'disappearing structure' of palacontology, is the phylctic tree which adorns the end of many good as well as superficial papers; and recently, because of its extremely bricf life, has fallen somewhat into disfavor. I d not think the present reaction against these 'trees' is a wisc one; we must remember they are the working hypotheses of our branch of science and serve to most clearly express present knowledge.

To iliustrate some of these principles of modern methods, let us first look at the evolution of the teeth in the rise of the mammalia. The teeth and the fect are the foci of mammalian evolution, the only direct points of contact with food and the earth. Their combined use in phylogeny has increased in interest, because their evolution has proved to be wholly independent. We recall Cuvier's famous law, of which Balzac said at the time : "Rebuilt like Cadmus cities, from a tooth."

No generalization has been more thoroughly routed than that of a necessary law of correlation between tooth and foot structure. Besides the orthodox clawed carnivores and heofed pachyderms of the $\varepsilon$ eat French anatomist, we have discovered hoofed carnivores such as Mesonyx, and clawed pachyderms such as Chalicotherium. Even the apparently lasting barriers of correlation, which Owen raised between the even and oddtoed ungulates, have broken down by Ameghino's discovery of 
a Litoptern odd-toed horse with an even-toed type of astragalus. Not only is there no currelation of type, but none in the rate of evolution. Hipparion, the most progressive horse in tooth-structure, protubly owed its extinction to its conservative prescrvation of its ancestral three tocs. For these reasons the teeth and feet, owing to the frequent parallels of adaptation, may wholly mislead us if taken alone; while, if consiclered together, they give us a sure key; for no case of exact parallelism in both tecth and feet between two unrelated types has yet been found, or is likely to be. This, I believe, is the one lesson of later work which reverts to older methods; we should not base either classification or descent upon the teeth or feet alone. Every additional character diminishes the chances of error.

The evolution of foot structure has now become a science and advances have been madc in the principles of progression from the plantigrade, pentadactyl serial types to the unguligrade, monodactyl alternating types which are of the greatest impertance in classification and phylogeny. It is surprising how little attention was given to ungulate foot structure between the time of Cuvier and Kowalevsky. Owen's generalization as to the Artiodactyl and Perissodactyl pes formed the one bright exception. Kowalevsky first directed attention to the importance of the more median metacarpals displacing or spreading to gain a stronger foothold upon the carpals as the lateral toes disappeared. Ryder also worked out the laws of reduction. The discovery of Phenacodus led Cope to the final generalization that the primitive ungulates were not only plantigrade but had some of their carpals and tarsals in vertical rows like bricks clumsily set with unstruck joints - and that one great law of evolution towards digitigradism was to produce cliplarthry or alternating joints. As he found this alternation differed both in degree and kind in different groups, he revived the comprehensive 'Ungulate' of Linnaeus and dividud all hoofed mammals exclusively upon their foot structure into five great orders.

Rütimeyer and myself have shown that fowcver successful and convenient this system appears, Cope's lines of clivision 
ignore the fundamentally different modes of evolution of the fore and hind fect; an animal may be a taxeopod in front and a diplarth behind or vice versa. Numerous exceptions to Cope's definitions are also found. The discovery of the aberrant ungulate foot types of South America further invalidates Cope's system and sustains the principle that to be permanent classification must be based upon at least two entirely diverse sets of characters. This docs not diminish the importance of the primitive taxeopod plantigrade type as one great key to the still unsolved problems of the primary relationships of the Condylarthra, Hyracoidea, Amblypoda, Proboscidia, Toxodontia, Litopterna, Artiodactyla and Perissodactyla. All these orders still stand apart in the dim past like so many mile-posts.

While Cope overestimates the feet in these larger divisions, many writers in Europe still depend wholly upon the teeth and ignore the wide degrees of divergence such as are indicated in the Perissodactyla for example in functional tetra-, tri- and monodactylism. By 'functional' we refer to tendencies which are not expressed in the bare digital formulas - and which have the same relation to the feet that the dental curve has to the teeth. The evolution of a monodactyl tendency is not the work of a century but of a geological period, a principle which we wholly ignore when we place the monodactyl Anchitheres with the tridactyl Palaeotheres, on the ground that their dental type and digital formulae are identical. How many toes an animal has is of far less importance than how these toes are being displaced and reduced.

\section{Lower Míesozoic Pro-Mammalia.}

With the exception of the triassic Theriodesmus of Se?lye, no mammal is known by its limbs or skeleton unt" we reacn the basal Eocene; in studying the first steps in the rise of the mammalia, we are thus practically driven to the teeth alid jaws alone. In these straits of the fossil-hunter, embryology has lately come famously to aid.

Assuming their remote reptilian origin, agreeing with Baur and Kükenthal that the theromorph reptiles were parallel with 
rather than ancestral to the mammals, and therefore placing before both groups the hypothetical Sauro-mammals in or below the Permian, we come to the old question which Huxley discussed in his famous anniversary-address : "Wris there a succession between Monotremes, Marsupials, and Placentals, or a paraliei development from a common promammalian type ?" Then we look to the newer questions, "When were the Eden. tates and Cetaceans given off ?"

Modern tooth-science springs first from the recent demonstration, of Rutimeyer's hypothesis of 1869 , that the teeth of all the mammals centre around a single reptile-derived type. With a single exception, which I jelieve can be disposed of, various stages of trituberculism or a three-cusped condition have become the standard for the tecth, as pentadactyly has long been for the fect, except that this is developed within the mammalian stem, while our five fingers are a reptilian legacy. Second, it springs from the recent thorough exploration of the youngest jaws for evidences as to the primitive form and siceession of the teeth. This also supports the reptile theory of tooth descent by proving, what has been in considerable doubt, that the Promammalia rad a multiple succession of teeth like the reptiles, and that even some of the modern mammals retain dim traces of four series of tecth.

The brilliant discoveries of Kükenthal, Lechc, and Röse begin to show how in various wa, $s$ the mammals early modified the regular succession of all the teeth by suppression of parts of the multiple series; this is the first thing to consider. The next is how heterodontism arose, how the conic rows of teeth were specialized in different parts of the jaw for threc or four functions ; as a certain number of teeth took up cach function, the question arises whether this number or dental formula was ever the same in all the mammals, for we know it is very different now. After the teeth were thus divided, some functions became more important than others, and established a monopoly, causing first a marked cifference in the relative development of the series, which we may express in a dental curve, resulting finally in a loss of certain teeth. In the meantime began the special evolution of the form of the back teeth, or 
molars. Was this alike in all mammals, was it tritubercular? It is surprising how many problems of early relationship are at stake in these simple processes.

\section{Primitive Diphyodontism.}

What does succession really consist in? It now appears that Baume was right in denying that the first tooth is the mother of the second; for the teeth of the lower as well as the upper series, spring from the common epithelial dental fold (Schmelzleiste) which dips down from the surface and extends the whole length of the jaw; at intervals it buds off the dental caps (Schmelzkeim) of the first series; after these are separated off, the dental fold sinks and buds off the dental caps of the second series, always below and inside the first ; thus the fold is the mother and the caps are sisters, twins, or.triplets, according to the number of the series. In all young mammals, including the traditional monophyodont Cetaceans and Edentates, and excepting only the still unexplored Monotreme embryos, traces of two series of teeth have been found. Both Leche and Röse have detected evidence that the dental fold sometimes buds off parts of a third series, thus explaining the occasional reversion of supernumerary teeth on the inner side of the second series, and Leche has seen traces of budding preceding the first series - thus giving us vestiges of four successions!

All our perplexities as to the relations of the milk and permanent teeth, and the ingenious but mistaken hypotheses of Baume, Flower, Wortman, and Cope have sprung from our want of evidence of the regular and complete diphyodontism of the stem mammals. The solution in brief is that the 'milk teeth' and the 'true molars' are descendec from the first series, while the second series is represented by the 'permanent incisors, canines, and pre-molars' and rudiments of dental caps beneath the true molars. The mammals early began to diverge from this primitive diphyodontism in many ways ; apparently adapting the first and second series, respectively, to their infant and mature feeding habits; losing parts or all of one series or the 
other, and in some cases pushing teeth of the second series in among the first ; this intercalation has been a most confusing
factor to us.

In the Marsupials (Kükenthal) almost the entire first series became permanent; thus from the Jurassic period to the present time only a solitary fourth premolar of the second series has pushed out its elder-sister tooth, and Röse has second series ; the remer upper-incisor also pushes up from the as rudimental the second scries still persist as rudimental dental caps beneath the first, even bencath the Placent second molars! There are wide variations among the Placentals ; thus in the lowest existing forms, the Insectivora, Leche finds that in the Shrew (Sorex) the second series is suppressed entircly, while in the Hedgehog (Erinaceus) of the twelve permanent teeth in the anterior part of the jaws five belong to the first series and seven to the second. We thus meet with the paradox, that among the 'primitive' Marsupials and Insectivures the regular reptilian succession was early interrupted, while in all the 'higher' mammals the reptilian succession of two series was retained in the anterior part of the jaw. Beneath the posterior highly-specialized molar teeth of both Marsupials and Placentals, the second teeth were carly suppressed, although in the Edentates, which also originally had specialized molars, there is a typical succession of seven teeth behind the canine. These discoveries prove that the whale teeth, like their paddles, have acquired a secondary adaptive resemblance to those of the Icthyosaurs. How did the single and simple tecth of the Edentates and Cetaceans develop? Clearly by retrogression. As Leche points out in the aquatic Carnivora, in which the first series are degenerating, the single-series condition (nonophyodontism) advances step by step with retrogressive simplification of the tooth form (homodontism); thus in the true seals, the eared seals and the walruses, as the permanent tceth become simpler, the milk teeth become smaller. The Edentates, so widely scparated genetically, parallel the seals in tending to suppress the first series of teeth and simplify the crowns of the second series at the same time. We might jump to the conclusinn that this (n) 
gives us an explanation of the homodont and apparently mono. phyodont condition of the toothed whales, especially as it has been supposed they sprang from aquatic Carnivora, but in this Order matters were reversed, for the first series persisted and the seconcl series were suppressed and persist as a rudimental row of tooth caps buried in the jaw.

Each dental series has an adaptive evolution of its own, in Erinaceus the first series has an ancient and the second a modern form; in Ericulus both series are alike; in the Bats the first serics is homodont the second is heterodont (Leche); in the Edentates the first series is ancient and heterodont the second is modern and homodont (Thomas, Rheinhardt); so among the Cetacea and Ungulata.

What deep and ancient clefts the different laws of succession mark between the Marsupials and these three Placental groups.

\section{Primitive Heterodontism and Formula.}

Now that all mammals are led back to a distant diphyodont stem, it is also true that the further we go back both in palingenesis and embryogenesis, the more widespread heterodontism is - all modern homodontism proving to be secondary. The simple conic teeth of the porpoise, for example, bear a misleading resemblance to those of a reptile. Flower, Weber, Julin, and Kükenthal agree that the ancestral whales and edentates were heterodont and had a smaller number of teeth than the existing forms.

Heterodontism is then the second problem. When did the division of the teeth into incisors, premolars, and roolars occur, before or after the Monotremes, Marsupials, and Placentals separated? It is well settled that the canine was the first maxillary tooth, and developed from the most anterior bi-fanged premolar; also, from the discovery of complete succession, we must now define the first molar as the most anterior specialized or triconid tooth, not as the most anterior permanent tooth. It seems to me we now find strong evidence that the stem mammals had a uniform number of each kind 
of tceth; in other words, a uniform dental formula. The Monotremes are most in doubt as the existing forms The only to primitive heterodontism. forward when we learn whether. It will be a great step are Monotremes - ther or not the Multituberculates of the Duckbill is molars lack the intermerill upper in the Multituberculates, and look tubercles universally seen Trituberculate teeth. ceous rocks a remarke found in the cretaThlacodon; the jaw of Marsupial; it is like this animal is neither Placental nor that of the Multituberculates - and both All we can say, the degenerate modern Monotreme jaw. an archaic group, therefore, is that the Multituberculates arf they were probablyighly specialized even in the Trias, that functionally akin to the the Microbiotherials (Owen) nor to and a condheridae (Ameghino). With a dental mechanism trace of canines, exactly like that of the rodents, they show no molars was probably mode of evolution of their peculiar present vestiges of a primitied later in the rodents. They $I_{3} C$ ? $P_{4} . M_{4}+$. Thlaeodon dental formula, like this : so far as this doubtful palaeontows $C_{1}, P_{4}, M_{3}$. Thus, Monotremes had a typical formological evidence gocs, the Our next step is to formula.

Our next step is to unify the typici. 5. I. 3.4 of recent shown in his 3. I. 4.3 of higher Placentals. Thomas has probably lost one of recent Marsupials that they have observation, fortunatelye four typical premolars (pm. 2); this an embryonic germ of is partly confirmed by Röse's finding the Jurassic Marsupial this tooth. Ignoring the incisors of tral incisors to five, the Thomas raised the number of ancesMarsupials; Röse thereforest number known among recent formity when he showed made another step towards unia member of the second that the Marsupial $i .5$ is probably be reckoned with should not - Placentals have lost first. Now, if we suppose that the Placentals have lost one incisor, and one molar abundant 
evidence of which is found in Otocyon, Centetes and Homo, we derive as the ancestral formula of both orders :

Incisors, 4 ; Canines and Premolars, 5 ; Molars, 4.

The aberrant placental Cetacea point in the same direction as we read in the conclusion of Weber's fine memoir: "All the Cetacea sprang from a stem with a heterodont, but onlv partly specialized dentition (something like that of Zeuglodon, 3. 1. p. \& $\mathrm{m}:$ 7), . . . not direct from Carnivores or Ungulates, but from a generalized mammalian type of the Mesozoic period, with some affinitics with the Carnivora. . . . Zeuglodon itself branched off extremely early from the primitive line, and the heterodont Squalodon (mark its formula, 3. 1. 4. 7.) " branched off later from the toothed whale line, after the teeth had begun to increase in number and before homodontism had set in." It would be easier for us while speculating to take Squalodon and the Odontocetes directly from the Jurassic mammalian formula (3. 1. 4. 8.). As for the multiplication of this formula, we have found the way, says Kükentinal, by which numerous homodont teeth have arisen from a few heterodont molars, it is by the splitting up of the numerous triconid molars of Jurassic ancestors into thrce. He substitutes this hypothesis for the one advocated by Baume, Julin, Weber, and Winge, that the multiple cetacean teeth represent the intercalation or joint appearance of both the frrst and second series of teeth, owing to the elongation of the jaw - a view which is now disproved by Kükenthal's discovery of the second row beneath the first. Since even by Kükenthal's hypothesis the typieal Mesozoic mammals could not furnish as many tecth as are found in some of the dolphins, a likelier explanation than his seems to be that as the jaws were elongated the dental fold was carried back and the dental caps were multiplied.

The Edentates, like the Cetaceans, point back to heterodontism, and somewhat less clearly to a typical dental formula. We are here indebted to Flower, Rheinhardt, Thomas, Kükenthal, and Röse. It is their rudimental and useless first series which gives the evidence of heterodontism, while the second serics has become adaptively rootless and homodont. The especially aberrant feature is that a double succession exists 
- in the typical 'true molar' region. The adult nine-banded Aimadillo presents only eight maxillary tecth, seven of
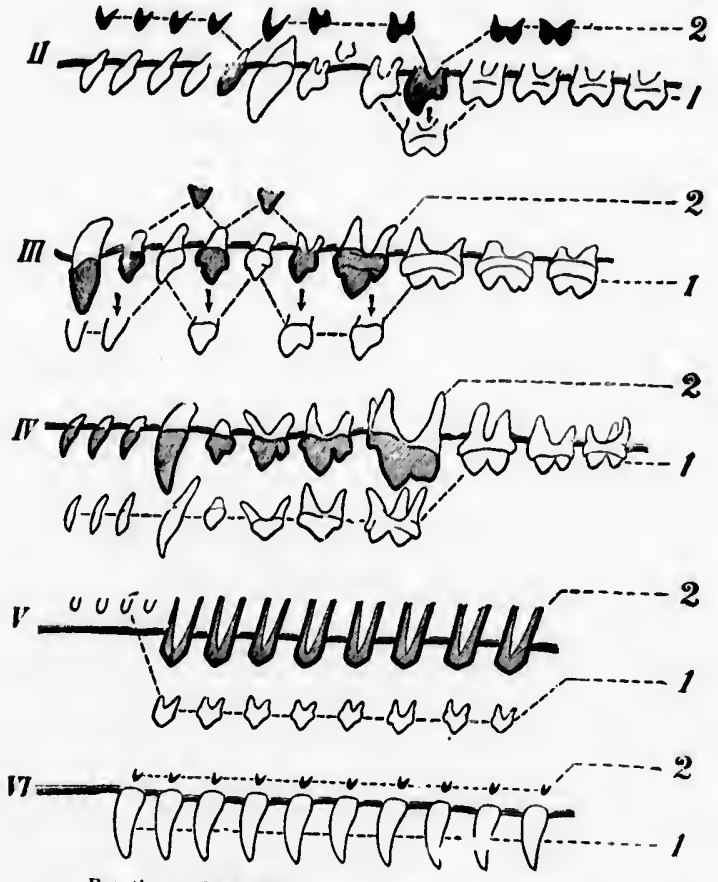

Kctutions of the Fïrst and Sicond Series of Tceth.

Placentals. $V$, Edentates. $V I$, CInsectivores (Erinaceus). IV, Iligher

which are preceded by two-rooted milk teeth (Tomes); in the embryo Leche finds fifteen dental caps, of which only thirteen are calcified; this number probably includes the four 
rudimentary incisors observed by Rheinhardt. In the aberrant Orycteropus (Aard-Vark), with ten adult teeth, Thomas finds seven milk teeth behind the maxillary suture (thus taking us into the molar region of the typical heterodonts). The last of these milk teeth is large, and two-rooted; bchind this are three large permanent posterior tecth, apparently belonging to the first scries. The large lateral tooth of Bradypus is suggestive of a canine. From this rapidly accumulating evidence it appears probable that the ancestral Edentates had four incisors, a canine and cight or more teeth behind it, tl.c double succession extending well back so that the first series did not become permanent at the fifth tooth, behind the canine as in the Marsupials and higher Placentals. If these are primitive conditions, as seems probable from comparison with fossil Edentates, they carry the divergence of the Edentates, like that of the Cetaceans, back into the Mesozoic period. Comparative anatomy and embryology thus point back to highly varied branches of a generalized placental heterodont stem in the Mesozoic, and a much earlier divergence than we formerly imagined. Now let us see what the early Mesozoic mammals point forward to.

There are three distinct and contemporary Jurassic types, the Multituberculates, the Triconodonts, and the Trituberculates. Are not these the representatives of the Prototheria, Metatheria, and Eutheria? In the archaic Multituberculates we have seen a monotreme type of jaw and vestiges of a typical ancestral formula. The Triconodonts are a newer group, perhaps derived from the Dromotheriidac (incipient Triconodonts) of the Trias although these appear to be aberrant; the typical forms extend from Amphilestes to Triconodon, and exhibit the first stages of development of the inflected Marsupial jaw. The Trituberculates include the Amphitheriidac and Amblotheriidac with true tuberculo-sectorial lower molars, like those of modern Inseativores; they alone exhibit the typical angular placental jaw, - no reason can be assigned for calling them Marsupials, excepting the traditional reverence for the Marsupial stem theory. Now, it is very significant that the average dentition of these old but highly 
diverse forms, namely, Multituberculates, 3. ? 4. 6., Triconoclonts, 4. 1. 4. 7., Trituberculates, 4. I. 4-5. 8., is also the dentition to which the existing mammals apparently revert.

The third problem is from. what type of molar tooth did the mammalia diverge?

\section{Primitive Tritubcrulism.}

There is a very general tendency among the vertebrates as a whole, fishes and reptiles as well as mammals, to form what are called 'triconodont' crowns by the addition of lateral cusps to simple cones. In the mammals alone, these three cusps pass into higher stages of evolution, through what is called 'trituberculy' in which these cusps form a triangle. The dis. covery of primitive wide-spread trituberculy by Cope, was a great step forward. In looking over the odontographies of Cuvier, Owen, Tomes and Baume, we find there is no suspicion of this common type around which the highly diverse mammalian molars centre. The molars of the clawed and hoofed mammals can now be compared, as we compare the hand or foot of the horse with that of the cat, because they spring fror a common type. All the specialized mammalian series, ungulates, primates, carnivores, insectivores, rodents, marsupials, are found playing similar yet indcpendent adaptive variations upon one type. We thus have a key to the comparison of all molars with each other, and with the reptile cones; take the human grinders for example: the anterior outer cusps in the upper jaw and the anterior inner cusps in the lower jaw are homologous with each other and with the reptilian cone. Leaving aside for the moment the Multituburculates and Monotremes, every known triassic, jurassic, cretaceous and basal eocenc fossil (excepting Dicrocynodon) is in some stage of trituberculy; all the known cretaceous molars are simple triangles above; all later fossil mammals also converge to trituberculy, until in the lowest cocene, every molar is tritubercular, and the early stages of divergence are so similar that it requires a practiced cye to distinguish the molar of a monkey from that of a horse. Embryology supports the evidence of these fossil series; thanks to the recent admirable researches 
of Röse and Taeker, we find in the primates, ungulates and marsupials, that every molar in the calcification of its dental caps is heralded by three concs placed in a triangle, and in the lower jaw these three cones invariably appear in the same order (protocone, paracone and metacone) in which they arose during the rentote geological periods.

It is necessary to mention this overwhelming palacontological evidence, because 'trituberculy' is still not universally recognized; Fleischmann and others have questioned the homologies of the upper and lower triangles, and two able writers, Röse and Forsyth Major, have independently proposed an opposition theory that 'multituberculy' or 'polybuny' is the mammalian archetype, the latter author believing trituberculy has become a 'dogma.' So far, however, from there being any decline of evidence, i am now able to add the Cretaccous mammalia to the tritubercular lists and bring forward evidence that the multitubercular molar insteal of being primitive was derived from the tritubercular; moreover, all the researches I have been quoting tend to draw the mammals without exception into one of three g. sat primary forms. The haplodont form, from which Dromotherium is just emerging in the Trias, is the oldest and nearest the reptiles; the triconodont or three cones in line, was a predominating lower Jurassic type ; the tritubercular or threc cones in a triangle (trigonodont, Ruitimcyer), was the prevailing upper Jurassic and later form. The final predominance of the tritubercular over the others was due to its possibilitics of mechanical adaptation to work of every kind its potcntial in evolution. Upon the polyphyletic theory of the origin of the mammals here advocated, we must admit, first, the independent cvolution of trituberculy in different phyla and second, the branching off of several great groups in the pre-tritubercular stages.

In the problem of precedence of type, I admit that as to antiquity there is nothing to choose. The contemporancity of the Rhaetic Microlestes (a plagiaulacid Multituberculate) and the upper Triassic Dromotherium (an early Trituberculate) is a puzzling circumstance; for, by my hypothesis, Microlestes was 
even at that time specializing from a more primitive Tritulser. culate arcestor. The molitr of this little animal is a narrow paucitubercular basin, not unlike that of several existin rodents which are of undoubted tritubercular origin ; and it is among the rodents we find the explanition of the Multituberculate molar. The molars of the mouse (Mus), and of certain kangaroo rats (Dipodomys and Perognathus), illustrate beautifully the recent stages between trituberculy and multituberculy, showing that the intermediate tubereles of Mus (also common in other placentals) give rise to the intermediate or third Multituberculate row. Then each row is fortified by additional tubercles; so that, finally, Perognathus, with its longritudinal rows of cusps and grooves, is in a similar stage of evolution to Tritylodon of the upper Trias of South Africa. This proves that the tritubirular molar has the potintial of a typical multitubcroular. Add to this the fact that the premolars of many Multitubereulates (Ctenacodon, Bolodon, Chirox, ) are tritubercular, and we have strong indirect evidence that the Multituberculates had Trituberculate ancestors. As for Röse's fusion theory of Multituberculate origin, it may be pointed out that the oldest types, with an abundance of primitive reptilian cones to fuse, have only five or six cusps, while the newest types, remote from the reptiles, have as many as twenty-five cusps. Fleischmann's objection is of a different character; he believes, from his studies of the Insectivora, that Cope and myself have mistaken the homologies of the parts in the upper and lower molars, and endeavors to show that the posterior end (talon) of the lower molar is equivalent to the anterior end (trigon) of the upper molar. His position is shown untenable by a study of Spalacotherium and other jurassic types in which there is no talon below or above, and it is proved that the upper and lower trigons must be homologous. The tecth of this form should also settle Rösc's doubts as to the position of the reptilian protocone in the upper and lower jaws.

Examine evidence of another kind as to the primitive type. Retrogression inverts the order of evolution. We know this 1 Prof. J. A. Allen and Dr. J. L. Wortman kindly assisted me in this comparison. 
of Thylacinns, in which a tritubercular molar turns back into a triconodont. In the aquatic Carnivora, the sea!s, eared seals, and walruses, the triconodont is also retrogressing into the haplorlont. The inference is a fair one that the aquatic, like the terrestrial Carnivora, were originally tritubercular. With the Cetacea, both palaeontolcry and embryology take us back to a more or less typical triconodorc molar, not to the tritubercular. The Edentates also give feebler evidence of ancestral triconodont or tritubercular molar forms.

Thus, the tendency of late research is to show that all stem mammals were related in their double succession, in their dental formula, and in their primitive molar form. These features point, not to a succession, but to a unity of ancestry of the Monotremes, Marsupials, and Placentals.

\section{Divergence of the three Groups.}

The discovery of the complete double series seems to have removed the last. straw from the theory of the Marsupial ancestry of the placentals, for the peculiar mode of suppression of the second series in the Marsupials has been constant since the Purbeck; this difficulty is added to the structure of the jaw, the epipubic bones, the profoundly different mode of foetal nutrition. None the less, any conclusion we can draw now as to the primary relations of the three great groups is more or less of a 'Schwindelbau,' and I put together the results of these later discoveries with a full realization of the temporary character of present conclusions.

The Pernian Sauro-Mammalia (Baur) with a multiple succession of simple conical teeth divided into: A, Theromorpha, which lost the succession and in some lines acquired a heterodont dentition and triconid single-fanged molars; B, Promammalia.

The hypothetical lower Triassic Promammalia retained a double succession of the teeth ; they became heterodont, with incipient triconid double-fanged molars ; dental formula approximating 4. 1. 4-5. 8. They gave rise to cin:e groups: I. The Prototheria which passed rapidly through che tritubercular 
into the multitubercular molars in the line of Multituberculates, and more slowly into trituberculy and its later stages in the line of Monotremes. Ii. The Metatineria or Marsupials tended to suppress the second scries of teeth, except those intercalated with the first; by this and by reduction the formula became 5. I. 3. 4-6; the molars passed slowly through the triconodont into the typical tritubercular type. III. The Eutheria or Placentals divided early into a number of branches, in which there was heterodontism, but no uniform modification of succession, namely: A, forms suppressing the second series in the molar region only, and acquiring a typical Eutherian dentition, 3. 1. 4. 3-4. I. The Insectivores tended to partly suppress the anterior teeth of the second series or intercalate them with tecth of the first series; the molars became tritubercular. 2. The higher Placentals retained the succession of the first and second series as far back. as the first molar; the molars entered rapidly into trituberculy and its higher stages. B, iorms retaining the double succession in part of the molar region, and retaining more of the primitive dentition, 4. I. 4. 8 . 3. The Edentates branched off from an carly triconodont or tritubercular diphyodont stage, with numerous molars, and secondarily suppressed the first heteroclont series, and established a numcrous homodont sccond scries. 4. The Cetacea also branched off from a diphyodont, heterodont stage, and secondarily established a numerous homodont first scries, and suppressed the second scries.

\section{Origin and Evolution of Triturerculisi.}

'Concrescence' is the ncwest theory of cusp e:olution an expansion by Kükenthal and Röse of vicws earlicr expressed by Gaudry, Magitot and Dybowski. As Kükenthal derives three conical Cetacean teeth by splitting apart a triconodont molar, he conversely derives a triconodont molar by bringing together of three reptile cones. Smith Woodward has called attention to the support the epidermal structures of the fishes give to this hypothesis, yet as applied to mammalian teeth, it comes from a one-sided Morphology 
which regards only the wonderful though mutilated chapters of Embryology when the untorn pages of palacontology are at hand. Between the Trias and the Puerco, we are, so to speak, ii at the birth of every successive cusp, and can observe positively that the law of cusp evolution is direct upsronth from the smooth slopes of the crown or from the cingulun: that fertile parent of new cusps. Each new cusp is usually preceled by an abraded surface, and prophesied by an excessively minute hillock. It follows from this that cusps range in size and height directly according to their agea principle beautifully demonstrated in some of the Mesozoic teeth. If the Kükenthal-Röse theory were correct, the oldest triconodonts should be iso-conid, whereas we know that the three equal cones of Triconodon are all a very late development; the earlier forms show the lateral cones receding to the needle-points of Dromotherium.

The tritubercular molar owes its survival to the oriyinal advantage of its triangular form, and to the possibilities of free cusp addition - as worked out by Cope, Wortman, Schlosser, Scott, and myself. Rütimeyer's term, 'trigonodont,' best expresses the primitive structure of the upper and lower teeth, as of two interlocking triangles with their open bases turned outward in the upper and inward in the lower jaw. These 'trigons,' cutting past each other, made a shear so perfect that many Insectwora retained it without further evolution. But in most Trituberculates a talon was next added to the lower molar (Jurassic stage) as a pestle crushing into the upper valley; this talon gradually widened into a broad heel supporting three cusps, as found in the Cretaceous. Consider the extreme antiquity of the three homologous cusps borne upon the back part of the human molar. This addition gave the opposed molars two shears and one crusher, and was so perfectly adapted to the needs of Lemurs and many Insectivores and Carnivores, in short, of most clawed animals, that they stopped at this point. Not so with the Herbivora, which required more extensive crushing surfaces. The upper molars, which had remained triangular through the Cretaccous and into the basal Eocene, began to 
develop a little talon, like that early seen in the lower molars, and at the same time both upper and lower molars entirely sacrificed their primitive cutting powers, and were converted from secodiont into bunodont types by bringing the primitive
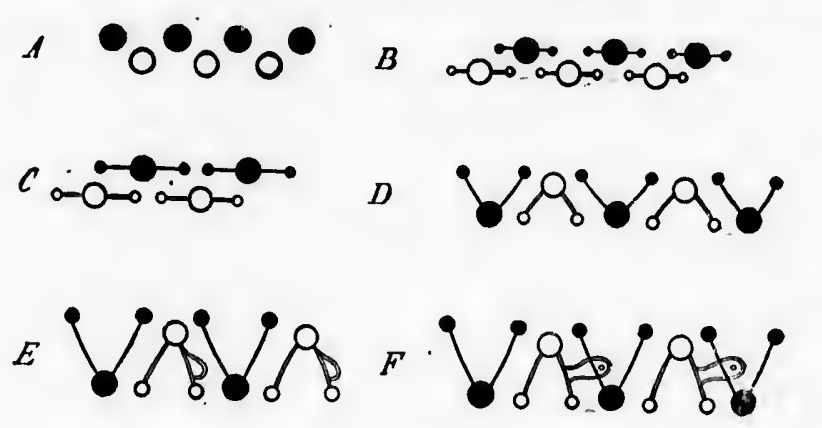

e original les of free Schlosser, ont,' best ind - lower pen bases ower jaw. shear so it further was next e crushing red into a iretaccous. omolocrous an molar. s and one

of Lemurs , of most - Not so e crushing triangular $\Rightarrow$ began to
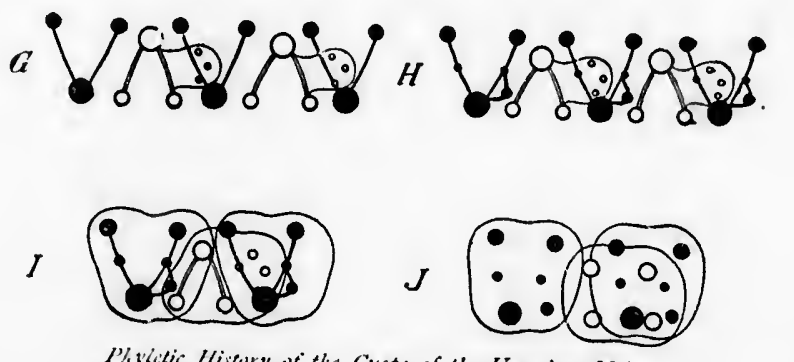

$A$, Reptilian Stage, Haplodont, Permiar. B, Protodont Stage (Dromotherium), Triassic. C, Triconodont Stage (Amphilestes). D, Tritubercular Stage (Spala. cotherint). E, Tritubercular-tuberculo Sectorial, Lower Jurassic. F, The same, in Upper Jurassic. $G$, The same, in Upper Cretaceous. $Z$, The same, Puerco, Lower Eocene. I, Sexitubercular-sexitubercular, Puerco. J, Sexitubercularquadritubercular, Wahsatch.

trigons down to the level of the talons. At the same time, the upper molars acquired intermediate tubercles, and the triangular or oblique arrangement of the tubercles was shifted into the quadrangular or transverse arrangement. This outline is the result of fifteen years' observation. 
With square crowns (vs. triangular) and six conic cusps above and below the molars of the Artiodactyl and Perissodactyl Herbivora ended their first constructive period at that period, and started upon their modernization. From this point we direct our attention upon the numerous combinations of three or four forms assumed by these single cones. The important thing now is to determine at what period these combinations were established, for there is wide difference of opinion as to when ungulate divergence began. To this I refer later. Taeker has recently shown how every modern embryonic lophodont or sclenodont molar first cxhibits the archetypal cones of the primitive bunodont. This law, together with my own parallel stulies of the evolution of the
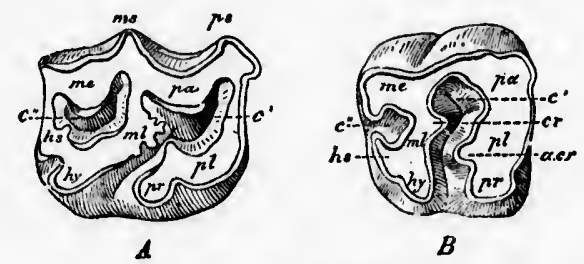

The Limits of Varia.ion.

A, Merychissus. B, Aceratkerim. Showing the secondary enamel foldings of the crests arising from the centres of the ancestral cones.

horse and rhinoceros molars, led me to the discovery that these embryonic primitive cones are also the main growth centers, for, in the upper Miocene, long after the perissodactyla have separated from each other, we see the influence of the archetypal form in the generic and specific variations of the molar:i. Compare the teeth of Merychippus and of Aceratherium, and imagine that you see underlying the diverse crests and crescents the simple bunodont molar of such a form as Hyracotherium leporinum of the London Clay. You will then notice that the character istic secondary feils and spurs of the Miocene teeth spring from the old bunodont cones, that the twro 'cement lakes' of Merychippus are equivalent to the two 'fossettes' of Aceratherium, because the 'crescentic 
spurs' of the horse and the 'crochet' and 'antecrochet' of the rhinoceros spring alike from the primitive 'intermediate tubercles.'

In view of these discoveries of the uniformity of mammalian molar type, a uniform terminology has become as necessary for the dental cusps as for the carpal and tarsal elements of the feet. Professor Gaudry's once admirable system, claborated in his 'Enchaincments,' was based upon the supposed division of the ungulate molar into the 'first lobe' and 'second lobe,' and is still followed in France. Yet it has two drawbacks : it precludes the comparison of the ungulate with the unguiculate molar, for neither lobe includes the complete triangle; still more inconvenient is the fact that we cannot compare the higher ungulates with the older Coryphodons and Periptychiclae in which the molars were developed upon the triangular plan; these teeth lave only the first lobe and half the second. The upper molars of Hipparion and Coryphodon illustrate the advantages of this new system of comparison and of terminology.

Scott has made a further advance in Odontology by working out the laws of premolar evolution or cusp addition. In many groups we know that from one to four of the premolars gradually acquire the exact form of the molars in order to further increase the grinding surface, and we should a priori expect that the cusps would be added in the same order, and therefore be homologous with the molars. This, as Schlosser and myself had observed, is not the case. Scott shows the order of cusp development in the premolars is very nearly the same in all the mammals, and yet is entirely different from the order followed in the molars. This. law again unexpectedly ties the clawed and hoofed mammals together; the sequence of cusps in palingenesis is similar to that observed by Taeker in embryogenesis, and Scott is justified in proposing a new terminology (protocone, deuterocone, trittocone, etc.) for the premolar cusps, which will in the end prove to be a great convenience.

I alluded above to the well-known extreme and very confusing similarity of the tritubercular molars in the early stages of divergence. Trituberculism is at once the cause of clearness 
and of doubt when we get back to the stem mammals of wicely different phyla. This has led to strange misconceptions of phyletic affinities as exemplified in Filhol's division 'Paclyyl'muricns,' a supposed mixture of lemur and ungulate stock. There was never any such mixture, and the question comes up how to distinguish unlike forms with like teeth? I have proposed to make use of a dental curve which will express the incipient atrophy of some parts, and hypertrophy of other parts of the series, a metatrophism which will naturally terminate in the reduction of some teeth, and excessive development of others. This has not been by any means fully worked out, but I believe it will prove to be of great service in directing attention to some of the initial tendencies of divergence, which are not expressed either in the dental formula or in the patterns of the teeth. Below are some of these curves. When worked

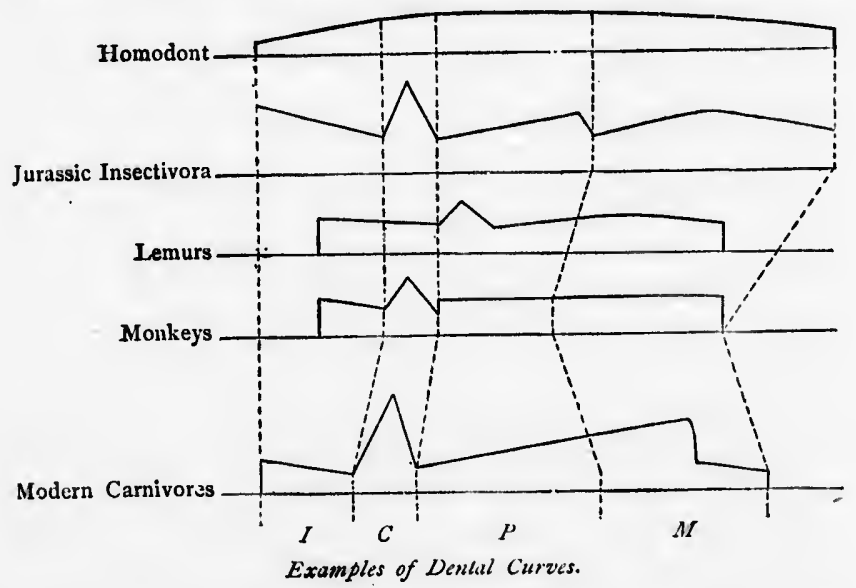

out by the composite method, we will find certain primary curves characteristic of the ordinal divisions, and minor curves distinguishing the lesser divisions. Of course the laws of parallelism will also be found in force here ; flesh-eating, insecteating, and grass-eating animals will be apt to have similar curves even when evolved in different groups, but here the dental formula and succession will come to our aid.

$$
8_{4}
$$


Breaks and Links in the Mesozolc Fauna.

By our hypothesis all three sub-classes flourished together during the American Mesozoic; the Marsupials disappeared, then the Monotremes, and by the end of the basal Eocene the Placentals were in cxclusive possession of the northern continent.

Although we have great reason to congratulate ourselves upon the rapid progress of discovery, there still remain great gaps in Mesozoic time between certain horizons and in the lineal phyletic series of both the Mesozoic and Cenozoic. For a time standard we may take advantage of the remarkably constant evolution of the Plagiaulacidae in the Mesozoic, and of the Equidae in the Cenozoic - as certain invertebrates are made use of in older rocks. The giooves and tubercles of Plagiaulax and the cusps and styles of the horses are added with the precision of elockwork, and supposing that the rate of evolution has been about the same, we can approximately estimate both the periods of deposition and the intervals as below.

\section{PLAGIAUlacidae.}

$\begin{array}{lccccc} & \text { Stonesfield. } & \text { Purbeck. } & \text { Laramle. } & \text { Puerco. } & \text { Cernaysian. } \\ \text { Number of Premolars, } & ? & 4-3 & 2 & 2-1 & \text { I } \\ \text { Grooves on Premolars, } & ? & 7-9 & 11-14 & \text { I } 2-15 & 14 \\ \text { Molar Tubercles: outer ; inner ; } & ? & 4: 2 & 6: 4 & 6: 4 & 9: 6\end{array}$

Estimating the geological intervals by dental evolution and faunal succession, there is first the great gap between the Trias of Microlestes and Dromotherium and the Jurassic of the Stonesfield slate; there is a relatively shorter interval, but still a considerable one between this and the Purbeck or Atlantosaurus beds. Then follows another long and very important interval between the Atlantosaurus beds and the Laramie (Upper Cretaceous). The gap between the Laramie and Puerco was relatively short as indicated by the comparatively limite. $i$ evolition both of the Plagiaulacids and Trituberculates. The Puerco itsclf was a long period in which the Plagiaulacids underwent considerable changes. Then follows an interval 
which it is most important to fill by future exploration, for between the Puerco and the Walssatch the differentiation of the even and the odd-toed ungulates must have occurred. The Wahsatch proper does not mark a very eytensive evolution of the forms it contains. It passes after a slight break into the base of the Bridger (Wind River) and then begins that splendid and almost uninterrupted succession of lake basins, terminating in the pliocene. I append a Table, to be compared with that published by Marsh in his admirable address of 1877 , and cxinibit the great progress of the last sixtcen years.

The general faunal succession is marked by the sudden appearanc's and disappearance of certain series and rise and fall of great groups. In the Trias appears the remarkable protodont or primitive-toothed Dromotherium; we cannot determine its Order at present. We still have no American fauna corresponding to the intermediate Stonesfield or England. In the jurassic Atlantosaurus beds the three supposed representatives of the Monotremes (multituberculates), Marsupials (triconodonts) and Placentals (trituberculates), appear in equal numbers; the latter are generally characterized by the primitive dental formula. In the Laramie the Multituberculates continue in great profusion, and the Marsupials and Placentals are also numerous.

The scrial succession of the Trituberculates from the Mesozoic is still an unknown chapter; we are utterly unable to connect the Dromotheriidac of the Trias, the Triconodontidac, Amphitheriidae and Amblotheriidac of the Jura with each other, or with any Cretaceous or lower tertiary mammals. The serial relations of the Multituberculates, on the other hand, liave been made much clearer by the discovery of the Laramie fauna. Cope and Marsh in this country, and Smith Woodward in England, have at last broken into the long barren Cretaceous. In studying the accurate figures published by Marsh and a large collection of teeth recently made for the American Museum by Wortman and Peterson, I find that this Laramie fauna is widely separated from the Jurassic in its general evolution, and as Gaudry, Lemoine and Cope have observed, it approaches more nearly the basal Eocene 
of the Puerco and the Cernaysian of France. The Multituberculates of the Laramic include the Plagiaulacidac, represented by Ptilodus, the form with two premolars, and Meniscoëssus, with two premolars and crescentic tubercles. Meniscoëssus has a smaller fourth premolar, and is found to liud off to the huge plagiaulacid Polymastodon of the Puerco. The only other Multituberculates found are those related to J3olodon of the Jurassic and Chirox of the Puerco. The other mammals of the Laramic range from the mouse to the opossum in size; they have superior molars of the simple tritubercular type-the low cusped or bunodont molar predominating in the upper jaw, and the tuberculo-sectorial in the lower. The dental formula is mostly the typical p. 4, m. 3. Yet, judging by the angular region of the jaws, we have here both Placentals and Marsupials. Some of the teeth remind us strongly of those in the Pucreo; their determination, however, is very difficult, for the jaws and teeth are almost entirely isolated. From another exposure of the Laramic, Cope has recently found the remarkable type Thlacodon-remarkable becausc it is a highly specialized trituberculate of typical dentition with a jaw which bears resemblance to that of the Multituberculates and of Ornithorhynchus. There is no placental angle nor strong marsupial inflection. This raises the sup. pusition that Thlacodon may be one of the persistent trituberculate Monotremes which we are now looking for.

In the Puerco or basal Eocene, a very marked change occurs, for the American fauna loses some of its cosmopolitan character, the multituberculates or monotremes die out and the marsupials are not found at all; in fact they do nci reappear in North America until the Miocene.

\section{Ancient and Modern Placental Differentiation.}

The Puerco is essentially an archaic fauna and is to be regarded as the climax of the first period of placental differentiation, a culmination of the first attempts of nature to establish insectivorous, carnivorous and herbivorous groups. These attempts began in the Cretaceous, and some of the 
types thus produced died out in tine Puerco, some in the Wahsatch and Bridger; only a few flesh-eaters survived to the Miocene. It is most important to grasp clearly tlic idea of this functional radiation in all directions of this old Pueren fauna, resulting in forms like the modern insectivores, rodents, bears, dogrs and cats, monkeys, sloths, bunodont and sclenodont ungulates, and lophodont ungulates. This was an independent radiation of placentals, like the Australian radiation of marsupials. What was the cause of the wide-spread extinction of these types? So far as the ancient clawed types are concerned, their teeth and feet seem to be as fully adaptive in many cases as those of the later unguiculates; the hoofed types were certainly inferior in tooth evolution, for all their molars evolved on the triangular basis instead of the sexitubercular; the most sweeping defect of both the clawed and hoofed types, was the apparent incapacity for brain growth, their bodies went on developing while their brains stood still. Thus the stupid giant fauna, the Dinocerata, which rose out of this period, gave way to the small but large-brained modern types. It is noteworthy that the latest survivors of this wreck of ancient life were the large-brained Hyaenodons.

Some of the least specialized spurs of this radiation appcar to have survived and become the centres of the second or mid. Tertiary radiation from which our modern fauna has cvolved. Yet we have not in a single case succeeded in tracing the direct connection. To sum up, we find on the North American continent evidence of the rise and decline and disappearance of monotremes and marsupials, and two great periods of placental radiation, the ancient radiation beginning in the mesozoic, reaching a climax in the Puerco and unknown post-Pucrco, and sending its spurs into the higher tertiary, and the modern radiation reaching its climax in the Miocene, and sending down to us our existing types.

Another Eocene centre was le $u$ S South America, which has of late dimmed the prestige of North America in yielding strange forms of iife. One theory of this Patagonian fauna is 
that it was an inclependent centre of functional radiation like the Puerco and $\Lambda$ ustralian, full of adaptive parallels, but not yielding to Europe or $\Lambda$ merica any of their older types. But Ameghino, to whose energetic rescarches we are chiefly in. debted, believes that he finds a lower locene life zone-a sort of south polar centre-which supplied both America and liurope. The Puerco he believes is no older than the Santacruzian which in turn is very much older than the Parana and Pampean formations, which Burmeister has made so well known. This yields the Homunculus patagonicus which parailels Cope's Anaptomorphus in presenting a dentition as advanced in reduction as that of man. $\Lambda$ meghino finds here the ancestors of the Macrauchenidae; he believes the Homolodontotheridae are the ancestore of the Chalicotheriidae thus deriving a buno-sclenodont from a lophodont type; the Proterotheriidac, he believes, replace the Condylarthra and Hyracotherium in the ancestry of the horses. Similarly the Microbiotheriidae are the stem of the creodonts and carnivores. I cannot coincide with any of these views. The Multituberculates are far older and widely different from the Abderites to which Ameghino traces their ancestry. I fully concur with the opinion of Cope, Zittel, Scott and others that this fauna is of somewhat later age, that it was directly connected with Australia and somewhat later with North America, supply. ing us, as has always been supposed, with our sloths. I quote from a recent acldress by Scott :

"The oldest mammals from South An"rica are those from Patagonia, which Ameghino has referred to tie Eocene, but which are more probably Oligocene or Miocene. This fauna is of extreme peculiarity and isolation; it is made up chiefly of edentates, rodents and ungulates of those very aberrant types known as Litopterna and Toxodontia, which are so widely different from the hoofed mammals of the northern hemisphere; together with some primitive forms of primates, crcodonts and marsupials. The marsupials are of extraordinary interest, for they comprise not only forms allied to the opossums, but also to recent Australian forms such as Thylacinus, Dasyurus and Hypsiprymnus. This is a most unexpected fact and seems to point unmistakably to a great southern cirsumpolar continent." 
The Puerco thus remains the most extensively known and productive lower eocene centre yet we have very slender threads of positive eviclence io connect its fauna with the later placental radiation.

The Creodonts of Cope occupy the same relation to the $m$ dern insectivores and carnivores that the Condylarthra do to the ungulates. The American group has been recently enriched by the discoveries of Wortman, and the literature by the careful revision of Scott. This author has divided them into eight families, placing the forms which most resemble the Insectivora in the new family, Oxyclaenilac. These families illustrate superbly the same law of functional radiation later repeated in the placental and marsupial carnivores. The Mesonyx family presents some analogies to the Thylacines. The modern bears are parallelled in the Arctocyons, with their low tubcrcular molars; Wortman and myself, with fresh matcri. als, have recently added $A$ nacodon to this family, a genus which was doubtfully regarded by Cope as an ancient ungulate. The Cats and Hyaenas are imitated in the Oxyacnas and Hyaeno. dons, some of the Miocene forms of which Scott suggests developed aquatic habits; as above noted, some of this family acquired large brains and persisted well into the Miocene. A still more remarkable likeness to the Cats is exhibited in the Palaeonictis family, which, unlike the Hyaenodons, forms its sectorials out of exactly the same teeth as the true cats. The first Amcrican Palaconictis was found two years ago by Wortman, and this author and mysclf have suggested that this may be the long-sought ancestor of the Felidae. The Civets are anticipated in the Proviverridac; yet both Cope and Scott, the highest authorities on this subject, believe that the dog-like Miacidae alone formed the connecting link between the Creodonta and the true Carnivora.

The foot structure of the ancient Pucrco ungulates is still only partly known. Cope has divided thes? animals into the Amblypoda and Coidylarthra. The Amblypoda are represented in the Puerco by a large form called Pantolambda, with selenodont triangular upper molars, and possibly by Perip- 
tychus, with bunodont triangular molars. The Pantolambda molars were, as Cope has shown, converted into those of Coryphodon, the great lophodont Amblypod of the Wahsatch, by a process exactly analogous to that in which the anterior half of a Palaeotherium molar was formed, that is, they acquired outer and anterior crests but no posterior crests. This Coryphodon molar type was still later converted into the Uintatherium type by swinging around the outer crest into a transverse crest. I have recently made a careful study of the fore and hind feet of Coryphodon, and have found that while the fore foot was subdigiligrade like that of the elephant, the hind foot was fully plantigrade, the entire sole resting upon the ground. The relation or connection between the Bridger Dinocerata and these earlier Amblypoda is still unknown. The Puerco Periptychus left no descendants. The other ungulates of the Puerco were the Condylarthra, rhe primitive Phenacolontidac, the supposed ancestors of the Artiodactyls and Perissodactyls. Much remains to be done to clear up this question.

\section{Succession of the Pcrissodactyls.}

In the Wahsatch and Wind River we find not only the last of the Phenacodonts and Coryphodonts and the first of the Dinocerata, but the first of the true Artiodactyln and Perissodactyls. Recent studies of Cope, Schlosser, Pavlow, Filhol have been directed to the phylogeny of the Perissodactýls with very different conclusions. I agree most closely with Schlosser, and have endeavored to show that the molar tecth give us a key to their natural arrangement as shown in this column.

... $\{$ Titanotheres.

$\cdots\left\{\begin{array}{l}\text { Horses. } \\ \text { Palaeotheres. }\end{array}\right.$

Tapirs.

... $\left\{\begin{array}{l}\text { Lophiodonts. } \\ \text { (Helaletes). }\end{array}\right.$

… $\left\{\begin{array}{l}\text { Hyracodonts. } \\ \text { Amynodonts. } \\ \text { Rhinoceroses }\end{array}\right.$

Upon one side the 'ritanotheres present the seleno-bunoriont extreme with most analogies to the Artiodactyla in tooth structure and in their truly Artiodactyl fore feet and bony horns. (If, as Cope supposes, the Diplarthra form a natural group, some Perissodactyls should certainly be more Artiodactyl than others.) The Horses and Palaeotheres diverge from the buno-selenodont 
ambda

Cory-

a, by a half of

zquired

This

e Uininto a of the it while ant, the g upon Bridger n. The igulates Phenayls and up this

the last of the PerissoFilhol yls with chlosser, ive us a $\mathrm{mn}$. res preme with ictyla in ly Artions. (If, ara form sodactyls tiodactyl 1 Palaeoslenodont

type towards the Lophodont; they were early separated in foot structure. The Tapirs, Lophiodonts, and Helaletes show well-marked transverse crests and incipient external crests. This brings us to the other Lophodont extreme, the Rhinoceroslike forms, with complete transverse and external crests. There are many other minor characters which support this as the natural arrangement of the Perissodactyls. I think it can be
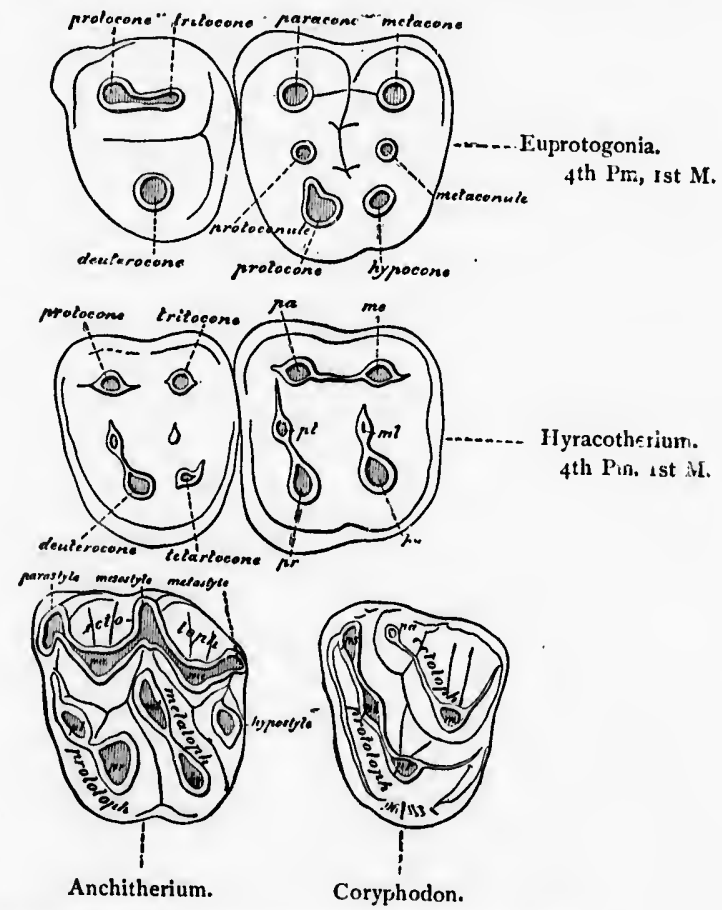

Homologies in the Horse and Coryphodon Molars and Premolars.

shown conclusively that these eight or nine series diverged from each other before the Wahsatch, and that all attempts to derive them from each otner in later periods will break down. They will be found to converge into the unknown SubWahsatch period, to stem forms as indicated by the brackets. 
One of the most decided reforms in the matter of classification is the use of the family division. Pre-darwinian writers considered animals as arranged in circles; post-darwinian writers all regard them as in vertical lines, giving off side branches. Classification should keep pace with phylogeny in palaeontology. Yet there are two clearly defined schools of classification to-day. The one, led by Flower, Cope, and Lydekker, practically adheres to the old circular system; according to this, comprehensive families are formed out of members of different lines of descent which happen to $b c$ in the same stagc of coolution; io: cxample, among the ungulates, a horse in the first stage of its evolution is called a lophiodont (i.e., it is placed in the Lophiodontidac), in the next stage it is called a palacothere (i.c., in the Palacothcriidac). The extreme anplication of this method by Cope has led to a total misundurstanding abroad of his real phylogenetic views. The other school, including Schlosser, Scott, Zittel, and myself, adopt the vertical system, according to which a horse is called a horse, a tapir a tapir, a rhinoceros a rhinoceros, from the moment when they clearly appear as such. I have attempted elsewhere to show that the circuinr system is confusing, that it ignores the divergence of structure which resulted from thousands of years of physiological isolation; that finally it is only possible when we define families upon the false system of single characters. In England and France the adherence to the circular system is largely due to traditional reverence for the Lophiodontidac, which has become an omnium gatherum for early odd-tocl ungulatesjust as were the Pachyderms of Cuvier until Owen proved that that term had no meaning. To-day, no one can say exactly what the Lophiodon itself was ; it appears to have been an aberrant and early extinguished line. In the vertical system the great stages of evolution may be inlicated by subfamily divisions, as in the following table. It is practically the same system as that which Flower applies to the existing mammals.

Al: the tendency of recent discovery has been to show that these lines are separate as far back as we can now trace them, 
that is, to the Wahsatch or Suessonian. Such being the case, we are no more justified in placing the ancient tapirs and horses in one family (Lophindontidae) than the modern.

In the matter of genera, opinion divides on different lines. Flower and Lydekker place all the extinct and modern Rhino. ceroses (except Elasmotherium) in one genus, while Cope

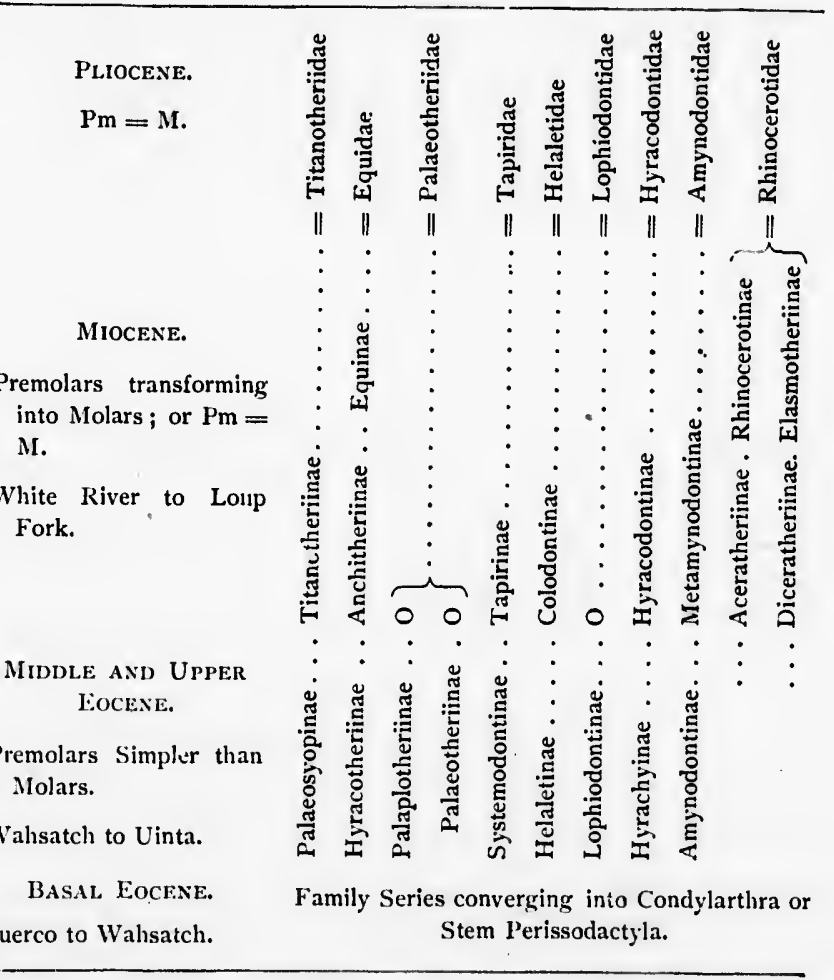

divides the Rhinoceroses into a large number of genera. Here we are dealing not with great separate lines of descent but with stages of evolution in the same or a few closely parallel lines. If we unite a large number of stages into one genus of $\mathrm{Rh}$ i:10ceroses, to be consistent we should do the same with the horses 
and tapirs. Nevertheless, it is very difficult, if not impossible, to agree as to what shall constitute a generic stage.

The Titanotheres have been traced by Cope back to Lanibdotherium in the Wahsatch; in the Wind River the true Palaeosyops is found, and in the Bridger this becomes the predominant perissodactyl family, and spreads out into a great variety of forms, which have recently been carefully described by Earle. In the Washakie there are some still larger forms, and Marsh has traced t?.e line throvigh the teeth of Diplacodon of the Uinta to the true Titanotheres. Still the origin of the flattened skull and remarkable anterior pair of horns has never been known; Hatcher reports species with very small horns in the base of the Titanotherium berls (Lower Miocene). Wortman has just reported to me the brilliant discovery of , upper Eocene (Washakie) Palneosyops with a flattened skull and rudimentary horns just appearing upon the iasals! This forms the desired connecting link.

The early history of the horses, probably starting with the Puerco Condylarth Euprotogonia, and passing through Hyracotherium, Pachynolophus, Epihippus, Mesohippus, is now familiar enough. It is the later history which requires elucidation, and is producing the most unexpected number of parallel lines of horses, out of one of which only our modern horse sprang. Here we are especially indehted to Cope, Yavlow, and Scott. By general consent Hipparion comes out of its old position in the true line as displaying the most extreme variations in the crowns of the molar teeth in compensation for the backward evolution of its feet. Scott has been especially investigating the upper Miocene horses; I quote from the MSS. he has kindly lent me, in which he proposes to remove also the classical Anchitherium of Cuvier. He says : "These American genera, Mesohippus and Miohippus may confidently be regarded as important members of the equine stem, while Anchitherium (of Europe) from present information would appear to belong to an abortive side branch leading to no permanent results." Scott has also discovered an important intermediate form linking Miohippus with Protohippus.

The Palaeotheres have not been found in America. 
The Tapir line has been traced by Cope and myself back to Systemodon of the Wahsatch, and Isectolophus of the Bridger and Uinta. These forms have simple premolars, but bear the most striking resemblance to the Tapirs in the molars both above ancl below. All previous attempts to determine the Miocene representatives of the Tapirs have been erroneous. Wortman and Earle have just published an account of two lower Miocene species of true Tapirs, which, both in foot and tooth structure, definitely carry the American Tapir line up to the middle Miocene, where it is again lost sight of. These species belong to the genus Protapirus, which Filhol has found in the Ol iqocene of France, thus adding an important geological parallel. The Wahsatch Tapirs were a little larger than the Horses or Hyracotheres which were about the size of a fox, and much smaller than the ancestral Tita.sotheres. Another family of small, slender perissodactyls were most nearly allied to the Lophiodons of Europe of any American forms.

These are the Helaletidae, distinguished by feet tending to monodactylism, and narrow hoofs like those of the deer; even in the Wahsateh Heptodon the lateral toes are quite short and raised off the ground. The molars, like those of the lophiodons of Europe, are intermediate between those of the Tapir and the Rhinoceros, but both tecth and feet preclude our uniting these forms either with the Tapirs or with the Hyrachyus family, as Cope has done. The Bridger successor is Helaletes, which Marsh mistakenly supposed was an ancestral Tapir, and the integrity of this line is now firmly established by the discovery of the Miocene Colodon. This is described by Marsh as a successor of Helaletes, and Wortman and Earle have just published an account of the teeth and feet, showing that Colodon is widely separated from the contemporary Tapirs, and is the last member of the Heptodon-Helaletes line.

The Rhinoceroses of America comprised the true Aceratheriinae and Diceratheriinae, and what may be called the pseudo-rhinoceroses, the Hyracodons and Amynodons; all these forms present the true Rhinoceros molar pattern, but they diverge most widely in the structure of the anterior teeth and of the feet. The Hyracodons first appear in the numerous and 
diversified Hyrachyus of the Bridger, sume of which exhibited rudimentary horns upon the back part of the nasals (Colonoceras); they retained a full set of equal-sized incisors and canines, and acquired a horse type of skull, skeleton, and locomotion. Scott has well named them the 'cursorial rhinoceroses.' Colonoceras proh.lbly did not, as Marsh has suggested, branch off into Diceratherium, for the horns of this true rhinoceros are developed at the ends of the nasals; the Hyrachyinae sent off as a side branch the deer-like Triplopus of the Washakie, and terminated in the Hyracodons of the lower Mioc?ne.

The Amynodons, at the time of their discovery by Marsh, were naturally supposed to be the long-sought Eocene rhinoceroses, but I have shown that no Amynodon can fill this rôle. Garman's discovery of the skull of the remarkable Miocene Metamynodon tended to confirm my views, and I have now to report the discovery of many skulls and a nearly complete skeleton by the American Museum Expedition. This proves that the Amynodontida were remarkable side forms. In wide contrast with the true rhinuceroses, the upper and lower canines develop into huge, partly recurved tusks, like those of the boar. As in Elasmotherium, the premolars become greatly reduced, and the molars tend to hypsodontism. The lower molars are long and narrow, like those of the anomialous Cadurcotherium of the Oligocene of Europe - it is thus rendered probable that Cadurcotherium is not a sloth, as Filhol has suggested, but is an aberrant rhinoceros, related to, if not identical with, the Amynodons. The hypsodontism in some Metamynocivis teeth is accompanied by a partial loss of enamel. To complete the aberrant character of this family, we find that it has four equal-sized and completely functional toes in the forefoot, like those of the Titanotheres, not with the fifth toe reduced as in the contemporary Aceratheria.

The true Rhinoceroses, we remember, are distinguished by the entire loss of upper canines. Wortman has just reported finding rudimentary upper canines in both the milk and permanent dentitions of the older Miocene species. The 
true rhinoceroses suddenly appear in the lower Mioceue of America and Oligocene of Europe; we have not yet traced them back. In a collection of lower Miocene skulls recently obtained for the American Museum we find that the premolars are still very simple. In the higher Oreodon Beds all traces of the superior canine are lost, and the premolars have become more like the molars. As the origin of the rhinoceroses still remains a mystery, so their later evolution needs clearing up. The American series suddenly terminate in the huge, hornless forms of the upper Miocene. I find there is still no unanimity of opinion in Europe as to the phyletic relationships of the Miocene, Pliocene and existing species.

\section{Succcssion of t'e Artiodactyls. ,}

The Eocene Artiodactyl phylogeny is still far behind that of the perissodactyls, but the Miocene and Pliocene succession has been worked up with great success and clearness by Cope and Scott. The latter says in a recent paper: "All the great groups of Artiodactyla are seen to arise independently from the Buno-Selenodonta which forms as it were a lake, from which several streams, flowing partly in parallel partly in divergent directions, are derived."

The Elotheriidae appear in Parahyus of the Bridger and Achaenodon of the Washakie, and terminate in the middle Miocene in the gigantic Elotherium ramosum, an animal with a skull three feet long, both the jaws and skull being armed with long branching processes. The true bunodont pigs and peccaries have not yet been found lower than the White River.

Scott has traced the Oreodons back to Protoreodon of the top of the Eocene. The aberrant Agriochoeridae, he believes, were doubtfully connected with the true Oreodons by a lower Eocene stem form. The true Oreodons, which exister in great herds $i_{1}$ the lower Miocene, have been divided by Cope and Scott into three parallel lines extending into the Loup Furk, namely, the large Merycochoerus, the medium-sized and more p.imitive Merychius and the small, highly-specialized Pithecistes. 
The Tragulines are represented by Leptomeryx, Hypertragulus and Hypisodus. Leptomeryx is believed to be a side member of the main fanily. Here I may speak of the recent discovery of the characters of the Protoceratidae, a new family with a remarkable ensemble of characters.

In 1891 Marsh described the female skull of Protoceras with a small pair of parietal protuberances. The male skull was found in 1892 . It is armed not only by upper canine tusks, but by four pairs of cranial protuberances, two of which might be dignified by the name of osseous horns; it thus presents the armature of an Uintatherium upon a small scale. Besides parietal and two pairs of frontal protuberances, there are a pair of most exceptional maxillary plates. The fore foot is like that of Tragulus, while the hind foot is didactyl like the deer. We can at present form no iclea of its affinities.

The oldest American Artiodactyl certainly known is the tritubercular Pantolestes of the Wahsatch. Cope believes the line of American Llamas may have sprung from this, and have been continued through Homacodon of the Bridger. The first undoubted cameloid is Leptotragulus of the Uinta, a comparatively recent discovery. It has strikingly reduced feet for such an early form. Poëbrotherium of the White River and John Day has quite the proportions of the living llama; thence the line passes into Protolabis of the Deep River and John Day. Scott believes that these forms are undoubtedly related to both the camels and llamas, and that in the Loup Fork, perhaps in the two species of Procamelus, the division occurs, $P$. angustidens passing into the camels, and $P$. occidentalis into the llamas. The Pliocene Homocamelus, Holomeniscus and Eschatius, Scott believes may represent a highly specialized side line of camels; while Pliauchenia, still imperfectly known, may belong on the llama side. The deer represented by Cosoryx and Blastomeryx are, so far as we know, not of American origin, for they first appear in the Upper Miocene at Loup Fork. 
The Ancylopoda.

The order Ancylopoda Cope presents the most signal exception to the law of correlation. It is only quite recently that Filhol, Forsyth Major and Depéret have brought together the sloth-like phalanges with the ungulate type of teeth of the Chalicotheriidae. Since 1825, when Cuvier described the phalanges from Eppelsheim as those of a 'pangolin gigantesque', referring to their deep elefts, and 1833, when Kaup named the teeth, these stru:ctures were always considered distinct. It is probable that Moropus and other supposed Sloths described by Marsh from our Miocene also belong in this exceptional order. As now restored by ' ol and myself, this remarkable Chalicotherium had a git . less clumsy than the Sloth, and something between a huge cat and a hoofed animal; it combined the skull of a primitive ungulate with the molars of an eocene titanothere, for the premolars are simple. The limbs, wrist and ankle bones are chiefly ungulate and perissodlacty! In viewing this combination of characters, the first question to settle is which set of characters is secondary and adaptive. I agree with Depéret, as against Filhol who recards this as an aberrant edentate, that the unguiculate characters are secondary; but I do not believ it is very near the perissodactyla. It seems to have sprung rather from the primitive ungulate stem before it had parted with its unguiculate characters. l'erhaps it came off from the Wahsati:in Meniscotherium, a member of the Condylarthra, which it very closely resembles in its skull and molar structure and in its dental curve. Marsh, by the way, has just aclded to our knowledge of this little Wahsatch genus by clescribing its fore and hind feet, which are more primitive than those of Phenacodus or Hyrax. While the Creodonta were imitating all modern carnivores, is it not possible that the Condylarthra gave off a sloth-like form for fossorial and semi-arboreal habits?

Last summer while this problem was being discussed, we wer brought to face with the exact counterpart of Chalicotherium which may be called a clazucd odd-locd form, by the surprising discovery of a hind foot, which represents a clarved cven-tocd 
animal. This was found by the American Museum party in the Protoceras beds of South Dakota, and has been named Artionyx. This foot has a truly Artiodactyl tarsus and metatarsus like that of the pigs or oreodons. Yet it possesses five toes terminating in large uncleft claws. It has been suggested by Wortman and myself that it represents an Artionychine (even-clawed) division and that Chalicotherium represents a Perissony hine (odd-clawed) division of the Ancylopoda; in other words, that a double parallelism exists with the Ungulata. Another explanation may be that these genera are highly specialized Artiodactyla and Perissodactyla respectively; Scott has made the ingenious suggestion, tending to support this theory, that the Artionyx foot is the long unknown foot of the aberrant oreodont Agriochoerus of Leidy. This summer will probably determine the truth of this suggestion, for two parties are hunting in the beds in which Agriochoerus and Artionyx occur.

Thus an immense number of problems still await solution, and demand the generous coöperation of European and American specialists in the use of similar methods of research, in the prompt publication of descriptions and figures, and in the free use of museum collections. I may be pardoned for calling general attention to the service which the palaeontological department of the American Museum is trying to render in the immediate publication of stratigraphical and descriptive tables of western horizons and localities.

\section{The Factors of Evolution.}

A few words in conclusion upon the impressions which a study of the rise of the mammalia gives as to the factors of organic evolution. I refer also to recent papers by Cope, Scott and myself.

The evolution of a family like the Titanotheres presents an uninterrupted march in one direction. While apparently prosperous and attaining a great size, it was really passing into a great corral of inadaptation to the grasses which were introduced in the middle Miocene. So with other families and lesser lines, extinction came in at the end of a term of 
development and high specialization. With other families no causes for extinction can be assigned, as in the lopping off of the smaller Miocene perissodactyls. The point is that a certain trend of development is taken leading to an adaptive or inadaptive final issue-but extinction or survival of the fittest seems to exert little influence in route.

The changes cn rontc lead us to believe either in predestination - a kincl of intermal perfecting tendency, or in kinetogenesis. For the trend of evolution is not the happy resultant of many trials, but is heralded in structures of the sime form all the world over and in age after age, by simsilar minute changes advancing irresistibly from inutility to utility. It is an absolutely definite and lawful progression. The infinite number of contemporary developing, degenerating and stationary characters preclude the possibility of fortuity. There is some law introd... ing and regulating each of these variations, as in the variations of individual growth.

The limits of variation seem to lie partly in what I have called the 'potential of evolution.' As the ö̈sperm or fertilized ovum is the potential adult, so the lecene molar is the potential Miocene molar. We have seen that the variations of the horse and rhinoceros molars, apparently so diverse, are really uniform, - is not this evidence that the stem perissodactyl had these variations potentially, waiting to be called forth by certain stimuli? This capacity of similar development under certain stimuli is part of the law of mammaiian evolution, but this does not decide the crucial point whether the stimulus is spontaneous in the germ or inherited from the parent. I incline to the latter opinion.

Columbia College, August 3, 1893. 


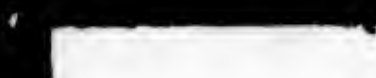




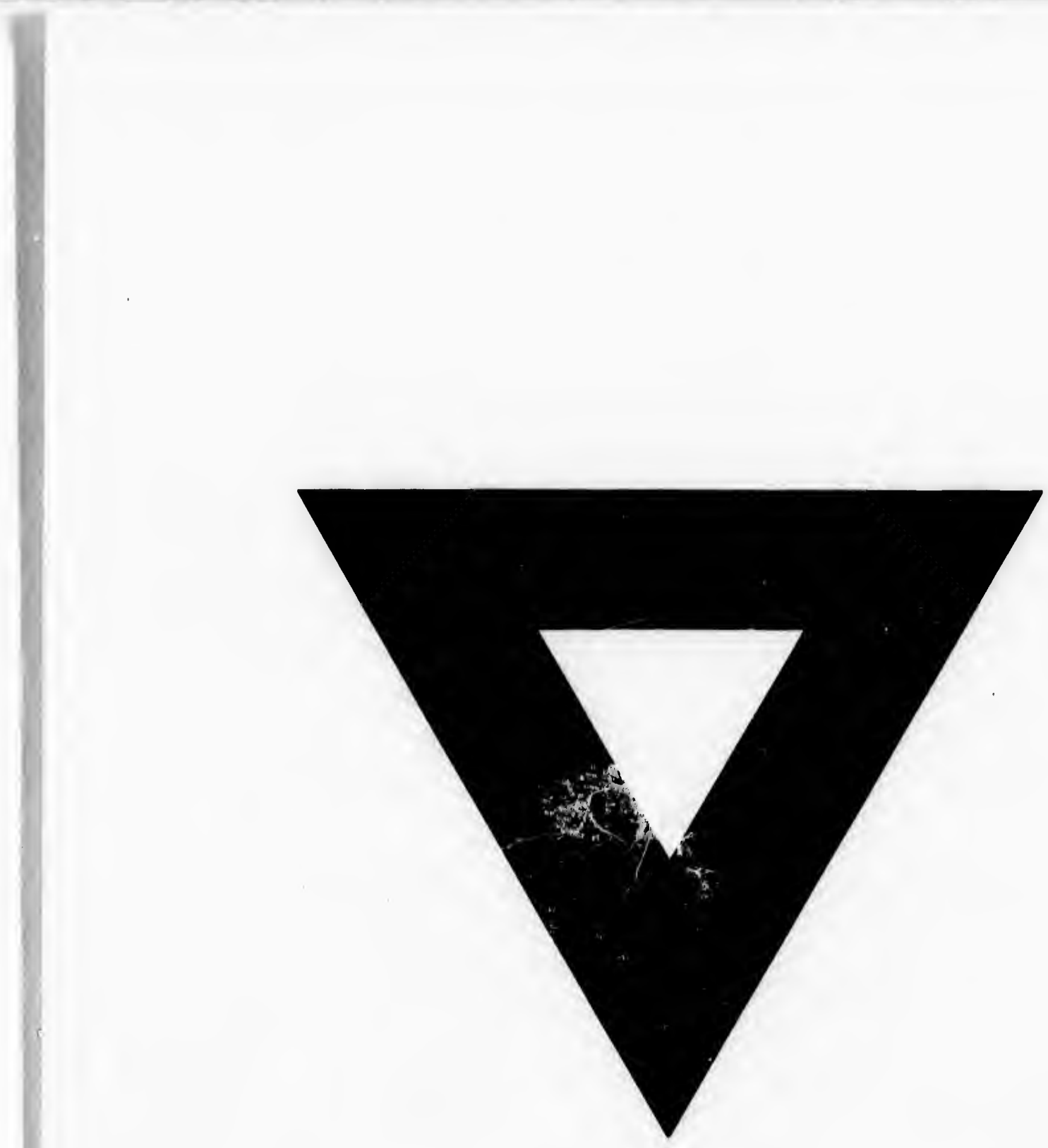

